University of Nebraska - Lincoln

DigitalCommons@University of Nebraska - Lincoln

Publications from USDA-ARS / UNL Faculty

U.S. Department of Agriculture: Agricultural

Research Service, Lincoln, Nebraska

2012

Modifying crops to increase cell wall digestibility

Hans-Joachim G. Jung

USDA-Agricultural Research Service, Hans.Jung@ars.usda.gov

Deborah A. Samac

USDA-Agricultural Research Service, debby.samac@ars.usda.gov

Gautam Sarath

USDA-Agricultural Research Service, Gautam.sarath@ars.usda.gov

Follow this and additional works at: https://digitalcommons.unl.edu/usdaarsfacpub

Part of the Agricultural Science Commons

Jung, Hans-Joachim G.; Samac, Deborah A.; and Sarath, Gautam, "Modifying crops to increase cell wall digestibility" (2012). Publications from USDA-ARS / UNL Faculty. 873.

https://digitalcommons.unl.edu/usdaarsfacpub/873

This Article is brought to you for free and open access by the U.S. Department of Agriculture: Agricultural Research Service, Lincoln, Nebraska at DigitalCommons@University of Nebraska - Lincoln. It has been accepted for inclusion in Publications from USDA-ARS / UNL Faculty by an authorized administrator of DigitalCommons@University of Nebraska - Lincoln. 
Review

\title{
Modifying crops to increase cell wall digestibility
}

\author{
Hans-Joachim G. Jung ${ }^{\mathrm{a}, *}$, Deborah A. Samac ${ }^{\mathrm{a}}$, Gautam Sarath ${ }^{\mathrm{b}}$ \\ a USDA-Agricultural Research Service, Plant Science Research Unit, 411 Borlaug Hall, 1991 Upper Buford Circle, St. Paul, MN 55108, USA \\ ${ }^{\mathrm{b}}$ USDA-Agricultural Research Service, Grain, Forage, and Bioenergy Research Unit, 137 Keim Hall, East Campus, University of Nebraska, Lincoln, NE 68583, USA
}

\section{A R T I C L E I N F O}

\section{Article history:}

Received 2 August 2011

Received in revised form 18 October 2011

Accepted 20 October 2011

Available online 25 October 2011

\section{Keywords:}

Cell wall

Digestibility

Ferulates

Lignin

Polysaccharides

\begin{abstract}
A B S T R A C T
Improving digestibility of roughage cell walls will improve ruminant animal performance and reduce loss of nutrients to the environment. The main digestibility impediment for dicotyledonous plants is highly lignified secondary cell walls, notably in stem secondary xylem, which become almost non-digestible. Digestibility of grasses is slowed severely by lignification of most tissues, but these cell walls remain largely digestible. Cell wall lignification creates an access barrier to potentially digestible wall material by rumen bacteria if cells have not been physically ruptured. Traditional breeding has focused on increasing total dry matter digestibility rather than cell wall digestibility, which has resulted in minimal reductions in cell wall lignification. Brown midrib mutants in some annual grasses exhibit small reductions in lignin concentration and improved cell wall digestibility. Similarly, transgenic approaches down-regulating genes in monolignol synthesis have produced plants with reduced lignin content and improved cell wall digestibility. While major reductions in lignin concentration have been associated with poor plant fitness, smaller reductions in lignin provided measurable improvements in digestibility without significantly impacting agronomic fitness. Additional targets for genetic modification to enhance digestibility and improve roughages for use as biofuel feedstocks are discussed; including manipulating cell wall polysaccharide composition, novel lignin structures, reduced lignin/polysaccharide cross-linking, smaller lignin polymers, enhanced development of non-lignified tissues, and targeting specific cell types. Greater tissue specificity of transgene expression will be needed to maximize benefits while avoiding negative impacts on plant fitness.cauliflower mosiac virus (CaMV) 35S promoter
\end{abstract}

Published by Elsevier Ireland Ltd.

\section{Contents}

1. Introduction ....

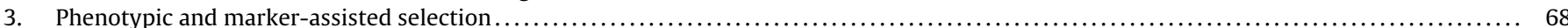

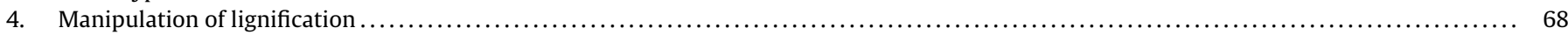

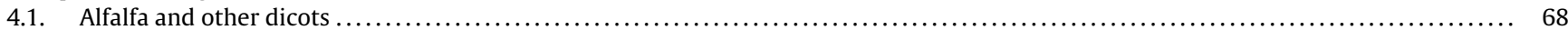

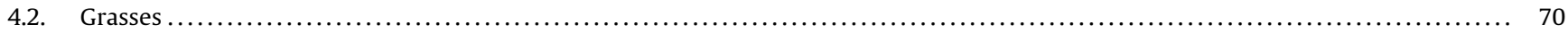

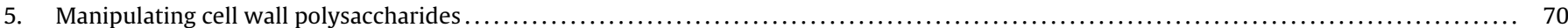

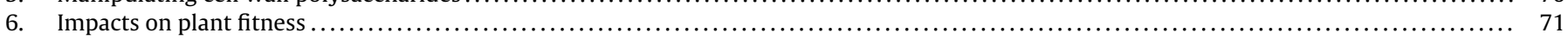

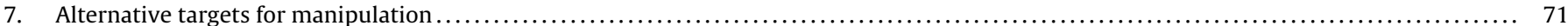

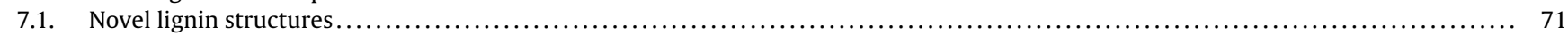

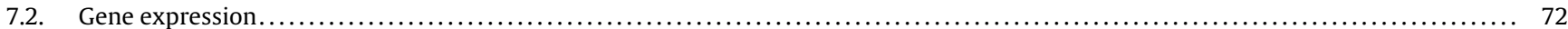

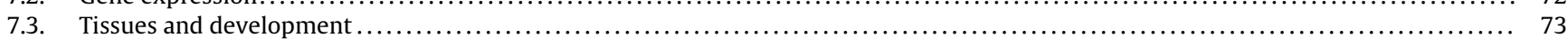

Abbreviations: 4CL, 4-coumarate:CoA ligase; ADL, acid detergent lignin; bm, brown midrib mutant; cam, cambium; CaMV 35S, cauliflower mosiac virus (CaMV) 35S

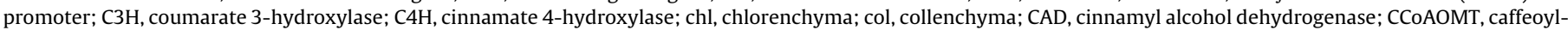

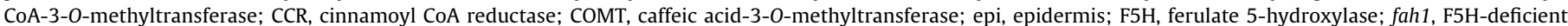

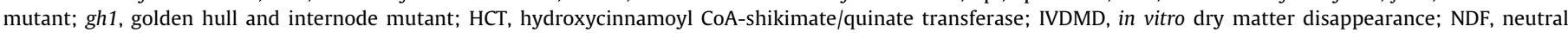

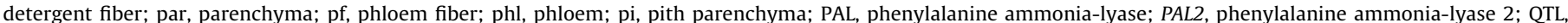

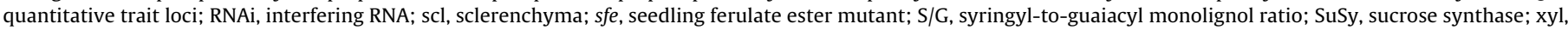
xylem.

* Corresponding author. Tel.: +1 612625 8291; fax: +1 6516495058.

E-mail addresses: Hans.Jung@ars.usda.gov (H.-J.G. Jung), Debby.Samac@ars.usda.gov (D.A. Samac), Gautam.Sarath@ars.usda.gov (G. Sarath). 


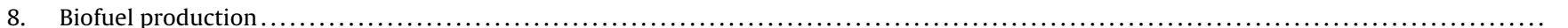

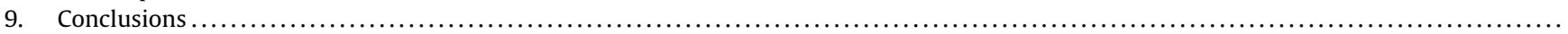

\section{Introduction}

Forages and crop residues are the primary feedstuffs used for ruminant animal production systems throughout the world, even in the seemingly grain-intense beef and dairy systems of North America. Digestibility of these roughages is variable because of the high concentration of plant cell wall material and generally less than for grains. The concentration of cell wall material in roughages is variable and increases with stage of plant maturity. Lignin concentration also increases with maturation of plants and is associated with reduced cell wall digestibility [1]. Ruminants evolved a complex, multi-compartment reticulo-rumen that provides an optimal environment for the microorganisms that digest cell wall polysaccharides [2]. However, lignification of plant tissues imposes a barrier to complete cell wall polysaccharide digestion in the rumen. Industrial conversion of biomass to ethanol or other fermentation products from the sugars in cell wall polysaccharides suffers from similar constraints due to lignification [3].

Increasing the digestibility of plant cell walls has been the focus of much research. Fig. 1 illustrates basic plant cell wall structure, and the processes of rumen digestion and biofuel conversion. Chemical pretreatments provide limited (anhydrous ammonia) to large (alkaline hydrogen peroxide) improvements in the digestibility of normally low quality annual crop residues [4]. None of these pretreatments are in regular use, primarily for economic reasons. In contrast, biofuel conversion typically requires harsh pretreatment processing [3]. Plant breeding to improve digestibility has been practiced for many years and resulted in the release of improved varieties [5]. Most of these breeding efforts have been directed at improving total digestibility rather than cell wall digestibility per se. More recently, molecular biology has been utilized to directly target lignification to improve cell wall polysaccharide digestibility in the rumen and for cellulosic ethanol production [6,7]. In this review we examine the progress achieved in genetic modification of forages and other roughage crops to improve rumen cell wall digestibility. While a short review of plant breeding approaches is included, molecular methods of genetic manipulation are emphasized because they offer greater possibility to specifically modulate gene function and tissue development. New targets for possible manipulation are proposed and differences in useful targets for improved cell wall polysaccharide hydrolysis by ruminants vs. for biofuel production are also discussed (also see Fig. 1).

\section{Process and limitations of rumen cell wall digestion}

It is necessary to understand the digestion process in ruminants and where limitations exist to critically evaluate the potential utility of modifying crops to enhance rumen digestibility of cell wall polysaccharides. Digestion of roughage cell wall polysaccharides by ruminants consists of four basic steps: particle size reduction of the plant material, enzymatic hydrolysis of the cell wall polysaccharides by the rumen microbial population, fermentation of the saccharification products to short-chain fatty acids, and absorption of the fermentation end-products [2]. Of these processes, the first two are of most concern for identifying targets for plant modification.

Particle size is reduced by mastication when forages are first ingested, and later again when partially digested digesta is regurgitated during rumination for additional chewing. Mastication increases the surface area available for microbial colonization and enzyme access to the cell wall polysaccharides. Compared with hydrolysis of starch, digestion of cellulose and hemicelluloses in the rumen is much slower [8]. Therefore, the ability of the rumen to retain digesta particles for extended periods of time is critical to maximizing cell wall polysaccharide digestion. As digesta particles reach a critical size and density, particles can exit the rumen via the reticulo-omasal orifice to the lower gut. Some additional cell wall polysaccharide digestion occurs in the large intestine; however, little further particle size reduction occurs. While in vitro rumen cell wall digestion is increased when roughages are ground finely, cell wall digestion is often reduced in vivo because digesta particles pass from the rumen more quickly [4]. However, animal performance (weight gain, milk output, wool growth) is usually greater when finely ground roughages are fed. Although quicker passage of digesta from the rumen of finely ground roughages will reduce the extent of digestion of cellulose and hemicelluloses, faster rumen emptying allows greater feed intake, which results in a net increase in digested nutrients. This competition between long rumen retention for maximal cell wall polysaccharide digestion and rapid digesta passage to allow greater roughage intake must be considered when designing the ideal plant for ruminant feeding.

The critical role of particle size reduction by mastication or grinding to cell wall digestion in the rumen is perhaps best illustrated by the observation that rumen bacteria digest plant cell walls starting from the lumen side of the lignified cells [9]. Even with extended incubation times measured in days, a thin lignified wall remains. Therefore, if lignified plant cells are not physically ruptured, it is impossible for rumen bacteria to access potentially digestible interior wall layers in adjoining cells. It has been estimated that approximately one-third of the cells within the typical size grass forage particle leave the rumen without being digested because of their inaccessibility by rumen microbes [10]. In contrast, non-lignified cell walls can be attacked by rumen bacteria from both the exterior and interior, and bacteria can access adjoining cells via digestion of intervening walls $[11,12]$. Lignification of cells is under developmental control, and the types and tissues that lignify can vary. For example, legumes contain many tissues (mesophyll, collenchyma, chlorenchyma, secondary phloem, cambium, and protoxylem parenchyma) that never lignify during development whereas only the mesophyll and phloem in grass tissues remain non-lignified at full maturity $[13,14]$. Leaves contain higher proportions of these non-lignified tissues than stems.

The rumen microbial population has a multitude of enzymatic activities that digest the complex polysaccharide structures present in plant cell walls. All cell wall polysaccharides are completely digestible when isolated from the wall matrix, but they differ in rate of digestion with cellulose and hemicelluloses being relatively slowly digested and pectins being rapidly digested $[8,15]$. These patterns in the rate of digestion for the various polysaccharides are similar during digestion of the wall matrix, with pectins still being more rapidly digested than cellulose and hemicelluloses $[13,16]$. However, because pectins reside in the middle-lamella/primary wall of cells and this region is heavily lignified and non-digestible in many tissues, the extent of pectin digestion can be limited because much of the plant pectin is in inaccessible wall layers. Legumes such as alfalfa (Medicago sativa L.) have thick, pectin-rich primary walls (collenchyma, phloem fibers) from which the pectins are 


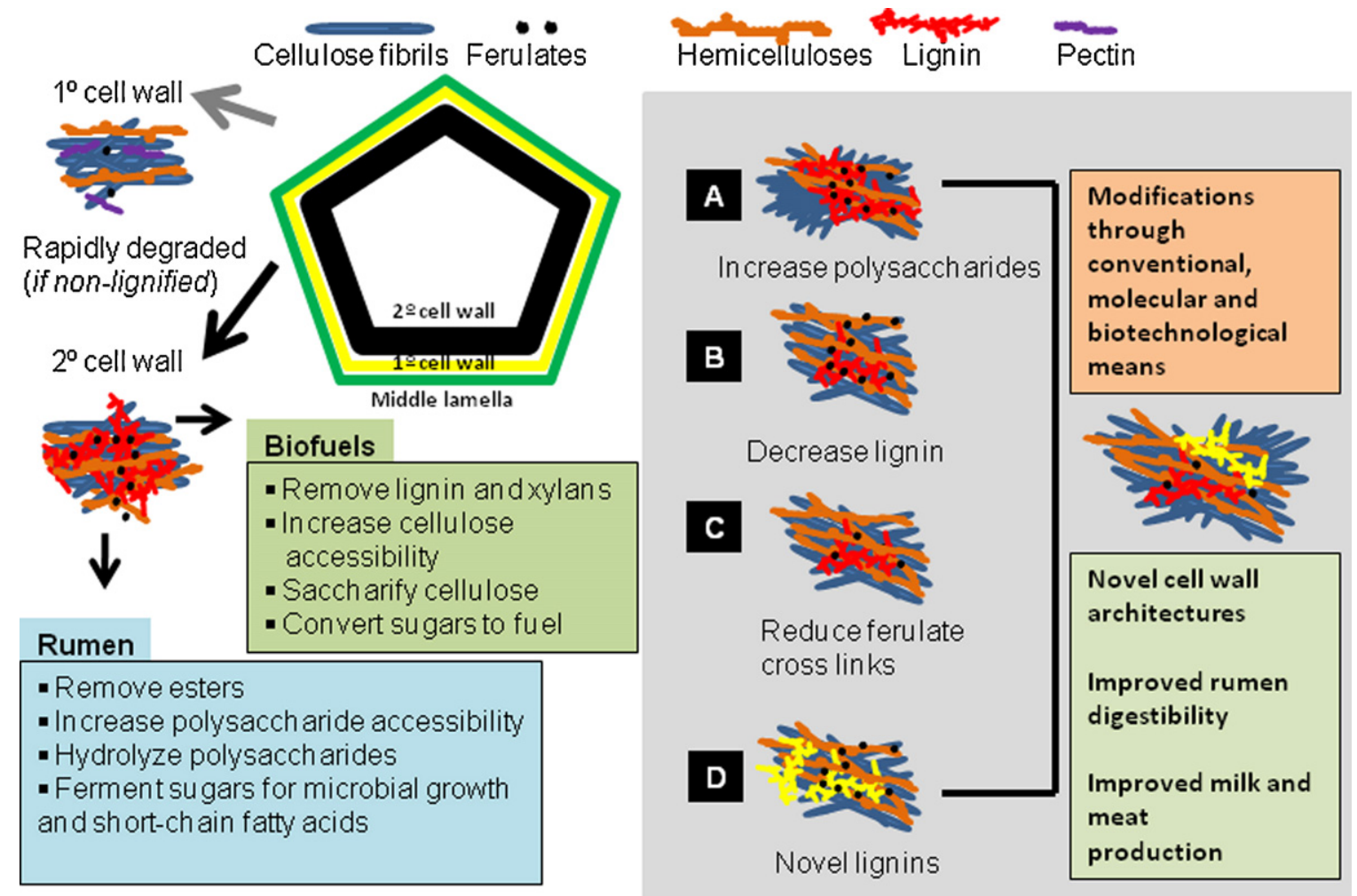

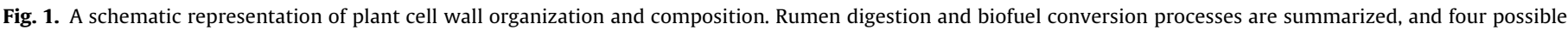
modifications to cell wall strcuture that may improve digestibility and/or conversion processes are illustrated.

extensively digestible [13], whereas grass cell walls contain little pectin. Non-lignified alfalfa stem tissues are digested rapidly and completely whereas thick-walled, lignified tissues such as xylem fibers show very little digestion by rumen microbes (Fig. 2). In contrast, lignified and thick-walled maize (Zea mays L.) sclerenchyma tissues are slowly but extensively digested; however, the original primary wall layer remains undigested $[9,16]$. The few non-lignified grass tissues are rapidly and completely digested.

\section{Before Digestion}

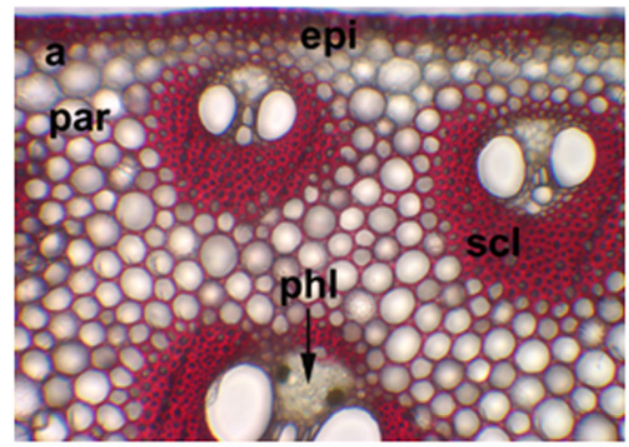

Maize

Alfalfa

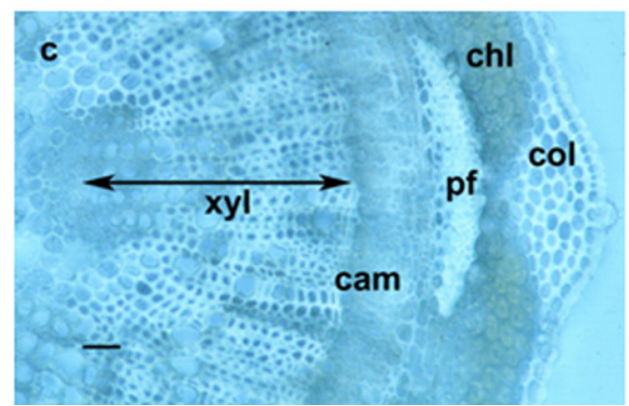

After Digestion
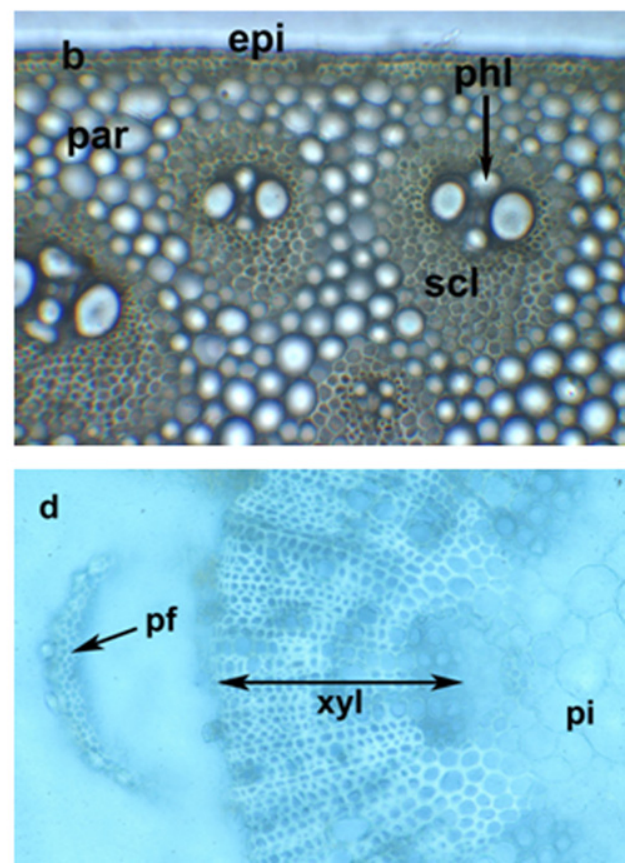

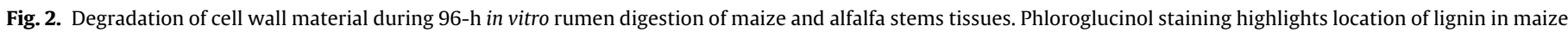

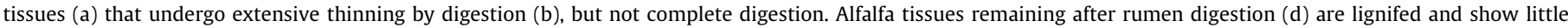

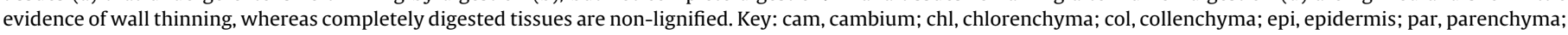
pf, phloem fiber; phl, phloem; pi, pith parencyhma; scl, sclerenchyma; xyl, xylem. 


\section{Phenotypic and marker-assisted selection}

Extensive breeding effort has been directed at forage species to improve in vitro dry matter disappearance (IVDMD). This assay simulates processes taking place in the rumen, an anaerobic digestion phase by rumen microbes followed by acid-pepsin digestion as occurs in the abomasum (the true stomach). This work has led to release of improved cultivars with increased animal performance [5]. Selection for IVDMD does not directly select for enhanced cell wall digestibility because most non-cell wall plant constituents are soluble in the IVDMD assay, which means that these nutrients are by definition $100 \%$ digestible. As a result, IVDMD actually selects for a combination of low cell wall concentration and cell wall digestibility. Selecting for IVDMD can be an effective technique for improving overall forage quality, but it is unlikely to be optimal for improving cell wall digestion.

Two approaches have been used to breed for improved cell wall digestibility of roughage crops; (1) selection for altered cell wall concentration and composition and (2) direct selection for in vitro rumen digestion of cell walls. Studies that have selected roughage crops for altered cell wall concentration and composition utilized the detergent fiber analysis system because digestibility is generally correlated with these measures [2]. The detergent system is a gravimetric analysis system based on solubility of cell wall structures and other plant constituents in neutral and acid detergent solutions. Unfortunately, the detergent fiber system has demonstrated inaccuracies relative to the cell wall components that the detergent fractions are assumed to measure [17]. Neutral detergent fiber (NDF) has been used as a surrogate measure for cell wall concentration and is generally similar to actual cell wall concentration for grasses, but under-estimates legume cell wall concentration because pectin is soluble in the neutral detergent solution [17]. A sizeable fraction of the lignin in plant cell walls, particularly for grasses, is soluble in acid detergent solution, which results in acid detergent lignin (ADL) under-estimating lignin concentration [18-20]. These issues with the detergent system must be kept in mind when evaluating plant genetic modifications based on this analytical platform.

Divergent selection for NDF concentration was successful in maize, smooth bromegrass (Bromus inermis Leyess), and timothy (Phleum pretense L.) [21-23]. Similarly, selection for decreased acid detergent fiber (assumed to contain cellulose and lignin) was successful in timothy and alfalfa [22,24]. Lignin concentrations in alfalfa, maize, and timothy were reduced by selection for low concentrations of ADL $[22,23,25]$. Pectin concentration in alfalfa was increased by selection for neutral detergent soluble fiber [26]. But when NDF concentration in smooth bromegrass was reduced by selection against NDF, actual cell wall concentration and composition (measured as Klason lignin and polysaccharide component sugars) were not altered [27]. This suggests that selection for low NDF selected for uncharacterized cell wall structural features in smooth bromegrass that conferred greater cell wall solubility in neutral detergent.

Attempts to select for improved cell wall digestibility have been less frequent. In vitro rumen digestibility of NDF is heritable in grasses and progress from selection has been demonstrated [5]. The nature of the changes in cell wall composition and structure, or shifts in tissue proportions that are responsible for improved NDF digestibility have rarely been investigated. Genetic markers for cell wall traits should provide the opportunity to directly select for genes controlling cell wall development. In a review on improving cell wall digestibility of annual crops, Barriére et al. [28] concluded that marker-assisted selection can accelerate development of cultivars with improved cell wall digestibility once favorable alleles are identified. Quantitative trait loci (QTL) have been identified in maize that correlate with detergent fiber components. Numerous small to large effect $\left(R^{2}=1-32 \%\right)$ QTL for NDF and ADL were found for leaf and stem tissues of maize and sorghum [Sorghum bicolor (L.) Moench] [29-33], but few significant QTL for whole maize plants [34]. A few significant QTL have also been identified for NDF and Klason lignin concentrations in Arabidopsis thaliana [(L.) Heynh.] stems [35]. We are aware of only a single report of QTL for nondetergent fiber cell wall concentration and composition traits in the herbaceous portion of a crop (maize stover) [36], although QTL for maize and soybean [Glycine max (L.) Merr.] seed cell wall components have been reported $[37,38]$. The overall conclusion that can be drawn from these studies is that most cell wall related traits have numerous QTL but with small individual effects. As might be expected, QTL for lignin and measures of digestibility have been reported to co-localize $[34,36]$. However, there are no literature reports on actual progress in breeding using marker-assisted selection to improve cell wall digestibility.

\section{Manipulation of lignification}

Biosynthesis of lignin in plants is catalyzed by a suite of enzymes that convert phenylalanine to hydroxy- and methoxy-cinnamyl alcohols (Fig. 3). These alcohols are subsequently transported to the cell wall and incorporated into the lignin polymer by radical-mediated coupling catalyzed by apoplastic peroxidases and laccases [39]. Fig. 3 is adapted from recent flux studies of the lignin biosynthesis pathway [39-44]. Overall, these and similar studies have shown that lignification is relatively plastic and any number of different phenolic intermediates can become incorporated into the lignin polymer. As a result, mutant and transgenic plants can have similar overall lignin content as wild type plants, but different proportions and types of monolignol components. Extensive research has been done on transgenic manipulation of lignin biosynthesis in numerous plant species, and several comprehensive reviews are available that detail impacts on lignin concentration and composition from reducing activity of individual enzymes in the monolignol biosynthetic pathway using an antisense gene or interfering RNA (RNAi) approach [45-47]. As with all transgenic modifications, numerous events must be evaluated because the expression of the inserted gene is affected by its position in the genome. In the following discussion we focus only on results for the transgene events that had the greatest impact for each step in the monolignol synthesis pathway. Unfortunately, the actual statistical significance of several quantitative differences reported for lignin concentration and digestibility could not be ascertained because multiple studies reported replicated analysis of bulked plant material rather than true biological replication of the transgenic plants.

\subsection{Alfalfa and other dicots}

Down-regulation of most enzymes involved in monolignol biosynthesis: cinnamate 4-hydroxylase $(\mathrm{C} 4 \mathrm{H})$, hydroxycinnamoyl CoA-shikimate/quinate transferase (HCT), coumarate 3-hydroxylase (C3H), caffeoyl-CoA-3-O-methyltransferase (CCoAOMT), cinnamoyl CoA reductase (CCR), ferulate 5hydroxylase (F5H), caffeic acid-3-O-methyltransferase (COMT), and cinnamyl alcohol dehydrogenase (CAD) was studied in alfalfa [48-52]. Reduced activity for all these enzymes, except $\mathrm{F} 5 \mathrm{H}$ resulted in lower lignin concentrations, although the magnitude of the alterations to lignin concentration varied among lignin analysis methods. For example, Klason lignin concentration was reduced by both CCOAOMT and COMT down-regulation, but ADL was only lower for the CCoAOMT events [53]. Lignin composition, and presumably structure, was altered by all of the transgenes with some causing increases (HCT, C3H, CCoAOMT, and CAD) and 


\section{Generalized lignin monomer biosynthesis pathway}

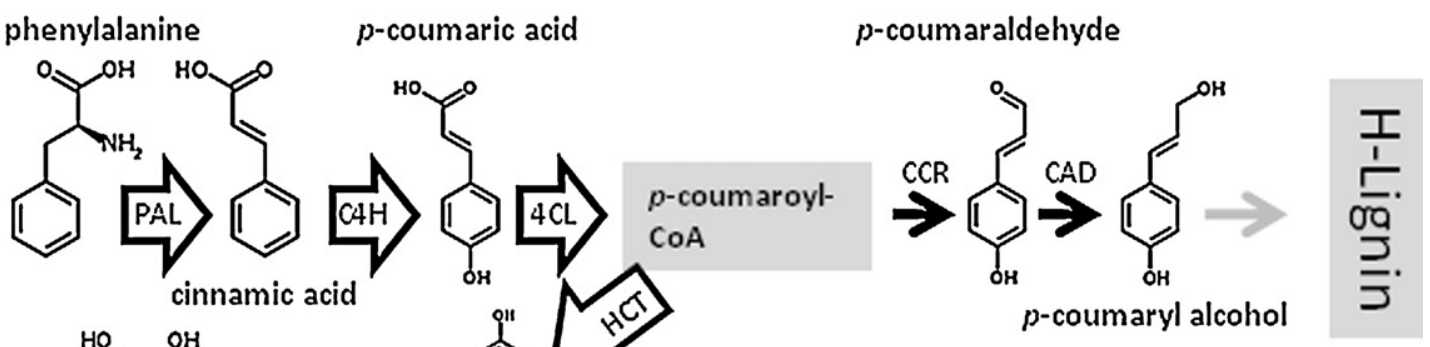

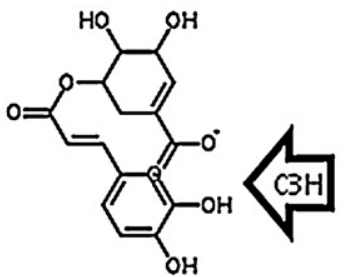

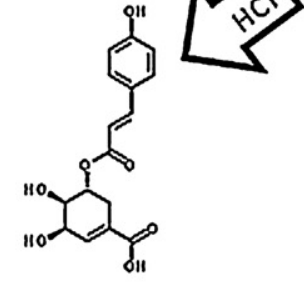

caffeoyl-shikimate p-coumaroyl-shikimate

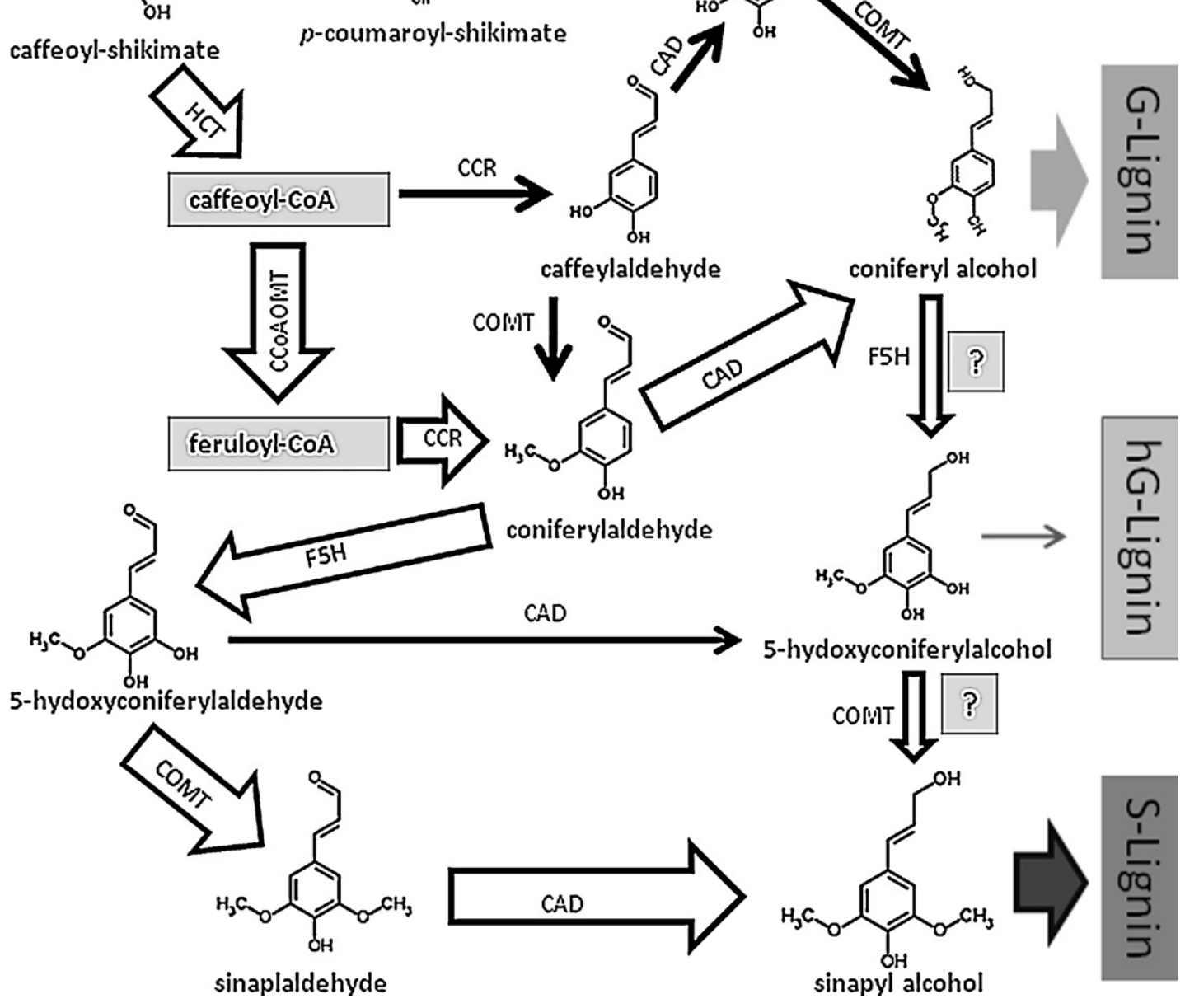

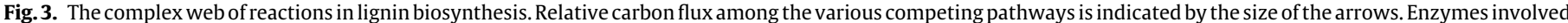

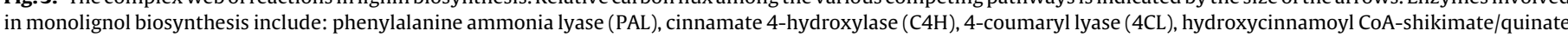

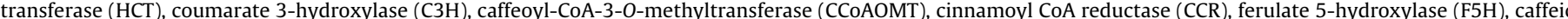
acid-3-O-methyltransferase (COMT), and cinnamyl alcohol dehydrogenase (CAD).

others resulting in declines $(\mathrm{C} 4 \mathrm{H}, \mathrm{CCR}, \mathrm{F} 5 \mathrm{H}$, and COMT) for the syringyl-to-guaiacyl monolignol $(\mathrm{S} / \mathrm{G})$ ratio. With the exception of $\mathrm{F} 5 \mathrm{H}$, down-regulation of all other monolignol synthesis enzymes resulted in increased digestibility as measured by various assays [48,51-54]. Changes in lignin concentration account for most of the improvements in digestibility rather than effects of lignin composition/structure as strong negative correlations were reported for lignin concentration with digestibility, but the $S / G$ ratio was not correlated with digestibility [52,54,55].
Data for transgenic down-regulation of lignin in other dicot species generally follow the alfalfa data. Reduced CCR activity in Arabidopsis resulted in reduced Klason lignin and NDF concentrations, and increased digestibility [56]. Tobacco (Nicotiana tabacum L.) plants down-regulated for phenylalanine ammonia-lyase (PAL) and COMT had reduced Klason lignin concentration, greater syringyl-type lignin content, and greater dry matter and NDF digestibility by cellulase [55]. Manipulating activity of enzymes relatively early in the monolignol pathway ( $\mathrm{HCT}$ and $\mathrm{C} 3 \mathrm{H}$ ) resulted 
in the largest decreases in lignin concentration and the greatest increases in digestibility [54]; however as discussed later, large reductions in lignin are generally associated with negative impacts on plant growth, development, and/or productivity.

In ruminant nutrition research, in vitro or in situ NDF digestion using rumen microbes is the most common assay for assessing cell wall digestibility. Only one report actually measured rumen cell wall polysaccharide digestibility in low-lignin alfalfa plants, with inconsistent improvements in digestibility for CAD down-regulated plants grown in the greenhouse (increased digestibility) or field (no change in digestibility) [48]. Most evaluations of low-lignin transgenic plants utilized IVDMD measurements of digestibility and, as discussed earlier, this method is susceptible to confounding of digestion with solubility. For example, down-regulation of several monolignol synthesis enzymes improved alfalfa IVDMD but NDF concentration was also reduced, which suggests some of the improvement in IVDMD was due simply to less cell wall material in the transgenic plants [52]. Fungal cellulases have been used to assess NDF digestibility [53]; however, the extent of NDF digestion by these limited-spectrum enzyme preparations are often substantially less than by the rumen microflora. While we believe that transgenic reduction of alfalfa lignification has improved cell wall digestibility, assessing the magnitude of the response would be more reliable if standard in vitro rumen NDF digestion methods were used.

Down-regulated COMT and CCOAOMT alfalfa lines have been evaluated in livestock feeding trials. Hay intake and in vivo NDF digestibility were greater by sheep fed the reduced lignin hays; however, the response was greater for the COMT down-regulated alfalfa [57]. When the same hays were included as $50 \%$ of a mixed forage/grain diet fed to dairy cows, feed intake was not altered for either transgenic event and only the COMT down-regulated line improved in vivo NDF digestibility and milk production [58]. This difference in animal response to the two low lignin transgenics is not surprising because the COMT transgenic line had a greater reduction in lignin concentration than the CCOAOMT line, and also a larger increase in in vitro NDF digestibility.

\subsection{Grasses}

A series of spontaneous (maize) and chemically induced (sorghum and pearl millet [Pennisetum glaucum (L.) R. Br.]) mutations have been identified in annual $\mathrm{C}_{4}$ grasses that reduce lignin concentration, alter $S / G$ ratio, and improve cell wall digestibility [59]. All of these mutants have a reddish-brown coloration phenotype in the leaf midrib vein and on the lower stem, and are known as brown midrib (bm) mutants. The brown midrib mutants generally improve cell wall digestibility and/or livestock performance $[60,61]$. The genetics for the 12 brown midrib mutants identified to date in these three grasses was reviewed by Sattler et al. [62]. The CAD and COMT genes have been identified as responsible for two of the maize (bm1 and bm3, respectively) and two of the sorghum (bmr6 and bmr12, respectively) brown midrib mutants. The rice (Oryza sativa L.) golden hull and internode (gh1) mutant has been shown to be a $C A D$ mutant that slightly reduces both lignin concentration and the $S / G$ ratio, but has not been evaluated for ruminant digestibility [63]. Rice is the only $C_{3}$ grass which has been found to have a spontaneous mutation in monolignol biosynthesis. Although rice gh1 appears to be similar to the maize $b m 1$ and sorghum bmr6 mutants because all are $C A D$ mutants, rice gh1 mutants do not exhibit the brownish-red coloration of the leaf midrib observed in these other two species. This variability in coloration phenotype between the maize and sorghum brown midrib mutants and the gh1 rice mutant may explain why brown midrib-type mutants have not been noticed in other $C_{3}$ grasses or dicots rather than brown midrib mutants being limited to annual $\mathrm{C}_{4}$ grasses.
While some varieties of maize, sorghum, and pearl millet containing brown midrib mutants are commercially available to farmers, the number of varieties is very limited. Breeding progress with brown midrib mutations to create maize and sorghum hybrids is laborious because these mutations are recessive and both parents of hybrids must be homozygous for the mutated gene; heterozygous plants have the wild-type phenotype. A transgenic approach to creating functionally dominant brown midrib mutants would avoid this breeding bottleneck. The COMT gene has been transgenically down-regulated in maize $[64,65]$. These transgenic maize lines exhibited lower lignin concentration and $S / G$ ratios, and improved in vitro cell wall digestibility similar to what is observed for the spontaneous maize bm3 mutant. Down-regulation of this COMT gene in maize led to changes in the expression of several genes involved in cell wall development, both related and unrelated to lignin biosynthesis [66]. We are puzzled by the fact that there are no commercial transgenic bm 3 maize hybrids available given that the mutated gene was identified over 15 years ago [67], the functionality of the transgenic approach has been clearly demonstrated, and a transgenic bm3 hybrid would not require that both inbred parents be homozygous for the recessive natural bm3 mutation.

Transgenic technology has provided an opportunity to extend down-regulation of monolignol biosynthesis to perennial grasses. Lignin deposition in tall fescue (Festuca arundinacea Schreb.) stems correlated with digestibility and activity of specific enzymes such as CAD and COMT [68]. Two transgenic tall fescue lines expressing a low $C A D$ transcript level and with lower enzyme activity had less lignin content and a lower S/G ratio, and IVDMD was improved by 7-9\% over wild-type control lines [69]. Down-regulation of COMT activity in tall fescue resulted in similar positive responses to those reported for the CAD down-regulated lines [70]. Recently, Fu et al. [41] used RNAi technology to down-regulate COMT in switchgrass (Panicum virgatum L.). Some of the transgenic switchgrass lines had greater in vitro digestibility. To date none of these low-lignin transgenic grasses have been tested in livestock feeding trials.

\section{Manipulating cell wall polysaccharides}

Although reducing lignin concentration has been the primary goal of efforts to genetically increase cell wall digestibility of roughages, there may be some advantages to modifying the polysaccharides present in the wall (Fig. 1). Significant progress has been made in understanding synthesis of cellulose and other cell wall polysaccharides, including identification of genes and their biochemical functions, but much remains to be understood about the regulation of the machinery involved in cell wall synthesis and the interactions among polysaccharide synthesizing protein complexes [71]. So far, altering expression of single genes involved in synthesis of cell wall polysaccharide precursors has had limited success in modifying cell wall composition.

Increasing cell wall pectin content is an obvious target for increasing roughage digestibility because pectins are more rapidly and extensively digested than cellulose or hemicelluloses $[13,15]$. A soybean UDP-glucose dehydrogenase gene was transferred into alfalfa in an attempt to increase pectin concentration [72]. It was expected that the greater flux of carbon from glucose to glucuronic acid would lead to further transformation to galacturonic acid, a major backbone chain component of alfalfa pectins. However, instead of observing any increase in the monosaccharide components of pectin, cell wall xylose concentration increased, overall stem cell wall polysaccharide concentration decreased, and lignin concentration increased [72]. The authors concluded that because pectins are composed of multiple monosaccharides arranged in several polysaccharide structures, increasing pectin content is likely to require coordinated increases in multiple pectin 
precursors. The increase in xylose content is perhaps not unexpected because UDP-glucuronic acid is also a precursor for xylose biosynthesis. Each of the UDP-glucose 4-epimerase genes were disrupted in Arabidopsis and found to reduce cell wall galactose content [73]. Although galacturonic acid content was not measured, disruption of UDP-glucose 4-epimerase might increase the substrate pool for UDP-glucose dehydrogenase and production of UDP-glucuronic acid, a precursor of homogalacturonan (pectin). Because synthesis of pectins requires the coordinated expression of numerous enzymes, it may be possible to regulate the pathway by modifying expression of key transcription factors in the regulatory pathway. However, our knowledge of the regulation of genes involved in cell wall biosynthesis and the biochemical controls of the carbon flow to cell wall polymers is still rudimentary.

Interestingly, reductions in lignin content by down-regulation of 4-coumarate:CoA ligase (4CL) in hybrid poplar (Populus spp.) and Arabidopsis are compensated for by an increase in cellulose content $[74,75]$. A reduction in lignin and compensatory increase of cellulose in hybrid poplar is also observed with over-expression of FLOWERING PROMOTING FACTOR 1, which is not directly involved in cell wall development [76], suggesting that cell wall content can be manipulated through a number of diverse pathways. However, constitutive down-regulation of $4 \mathrm{CL}$ is associated with negative effects on plant growth and development [75].

Increased concentrations of cellulose or other cell wall polysaccharides would increase the amount of potentially digestible carbohydrates in roughages; however, we caution researchers that increased concentration of cellulose does not necessarily imply that polysaccharide synthesis was increased. This is because concentration measurements are proportions; the components must always sum to $100 \%$. Therefore, when one component such as lignin is reduced by down-regulation, then one or more other components such as cellulose must increase proportionally. Verification that polysaccharide biosynthesis has actually been increased requires that multiplication of the polysaccharide concentration of the roughage by the total biomass yield of the plant be greater than in the wild-type plant. Unfortunately biomass yield of genetically manipulated plants is rarely provided.

\section{Impacts on plant fitness}

Reduced agronomic fitness (vigor, disease and drought resistance, productivity) has been routinely observed for plants with reduced lignin concentration. The brown midrib mutants in maize, sorghum, and pearl millet have reduced insect resistance, increased susceptibility to lodging, and reduced yield [77]. However, the degree to which negative effects are associated with brown midrib mutations is dependent on germplasm background. Divergent selection for IVDMD in multiple perennial forage species resulted in populations of plants with high and low lignin content [78]. Winter survival was compromised in high IVDMD switchgrass and orchardgrass (Dactylis glomerata L.) populations. Further studies with switchgrass [79] indicated that the relationship between lignin content and survival was only loosely linked, and winter survival improved in high IVDMD populations by imposing selection for survival as an additional breeding criterion.

Among the genes for monolignol biosynthesis, down-regulation of genes earlier in the pathway resulted in both less lignin and greater negative impacts on plant phenotype [51,52,54,56,80,81]. Typically, transgenic plants with severe reductions in lignin concentration were shorter in stature, produced less total biomass, and showed changes in sites of lignin deposition based on tissue staining. Xylem vessels were often distorted in shape when lignin concentration was reduced $[56,81,82]$, suggesting that impaired water transport may partially account for the observed dwarfing.
However, it was recently suggested that constitutive activation of defense responses in alfalfa with down-regulated HCT activity may account for the observed plant dwarfing [83]. It was hypothesized that this response occurred due to release of bioactive cell wall polysaccharides from tissues with reduced lignin concentrations. These HCT down-regulated alfalfa plants also had improved drought tolerance, which argues against impaired water transport through irregular-shaped vessels as the cause of dwarfing.

The simultaneous partial down-regulation of CCR and CAD in tobacco plants resulted in significantly reduced Klason lignin content in stems and an increased $S / G$ ratio compared to wild type plants, but growth was not negatively affected under controlled conditions [80]. Lignin deposition in these plants at the cellular and subcellular level was specifically reduced in xylem fiber secondary walls [84]. While aberrant deposition of lignin enriched in non-condensed units and deformed xylem vessels was observed in plants partially down-regulated for CCR, when both CCR and CAD were partially down-regulated, cell shape was near normal and non-condensed lignin was normally distributed. The authors suggest that plants can tolerate large decreases in lignin when decreases are targeted to specific cell types, such as xylem fibers. The research also supports previous observations of cell type specific expression of genes involved in monolignol synthesis.

\section{Alternative targets for manipulation}

\subsection{Novel lignin structures}

Because brown midrib mutants have both decreased lignin concentration and altered composition, it was hypothesized that lignin composition as measured by the $S / G$ ratio may partially account for the improved cell wall digestibility of these mutants [1]. Artificially lignified maize walls from cell culture and stems of the Arabidopsis $\mathrm{F} 5 \mathrm{H}$-deficient (fah1) mutant had even larger shifts in lignin composition for normal syringyl and guaiacyl monolignol units than walls in brown midrib mutants, but did not have altered cell wall digestibility $[85,86]$. These results support our earlier conclusion concerning low-lignin transgenic plants, namely that reduced lignin concentration and not altered $S / G$ ratio accounted for the observed improvements in digestibility. However, incorporation of various novel synthetic monolignols into lignin formed by the maize cell culture system actually improved cell wall digestibility, although much of the increase probably derived from reduced lignin concentration [87]. In contrast, addition of coniferylaldehyde units into lignin from maize cell culture depressed cell wall digestibility without altering lignin concentration [88]. This latter result is of interest because CAD down-regulation has resulted in the incorporation of coniferylaldehyde units into lignin [89]. However, the reduction in lignin concentration due to CAD downregulation has resulted in modest improvements in digestibility rather than reductions due to incorporation of unusual monolignols $[48,51]$.

Studies using isolated cellulose and a model polymer (polyeugenol) for lignin indicated that digestibility is reduced only when polysaccharides are chemically cross linked to lignin [90,91]. Grass lignin is cross linked to arabinoxylans by ferulate and diferulate molecules that are esterified to arabinoxylan and covalently linked to lignin by ether and other bonds (Fig. 1) [92,93]. These ferulate and diferulate esters appear to act as initiation sites for lignin polymer growth such that all grass lignin polymers may be cross linked to arabinoxylans [94]. The presence of ferulate cross links restricts cell wall digestibility by enzyme preparations and rumen bacteria independently of lignin concentration in a maize cell culture system [95-97]. In vitro rumen NDF digestibility was greater for plants with low ferulate cross linking and the relative negative 
impact of cross linking was twice as great as lignin concentration in several perennial grasses [98-100].

The putative seedling ferulate ester $(s f e)$ maize mutant had less lignin/arabinoxylan cross linking by ferulate ethers and had greater in vitro rumen NDF and cell wall polysaccharide digestibility at silage-stage maturity than near-isogenic wild-type maize [101]. Inclusion of sfe maize silage in a typical mixed ingredient diet fed to dairy cows improved in vivo NDF and cell wall digestibility, feed intake, and milk production [102]. Candidate genes involved in feruloylarabinoxylan biosynthesis have been identified [103-106], but it is yet unknown whether these genes influence cross linking or cell wall digestibility. Once the relevant genes involved in ferulate cross link formation are identified and cloned, the opportunity exists to improve cell wall digestibility of all grass roughages because ferulates are present in all grasses [107].

Another approach was used to reduce ferulate cross linking; a fungal ferulate esterase was engineered into tall fescue and specifically expressed in cell walls [108]. The transgenic plants had increased IVDMD. In a follow up study, expression of the fungal enzyme was targeted to specific cellular compartments of fescue plants. Plants expressing the esterase in the Golgi or in cell walls had lower ferulate ester and ether concentrations, and improved IVDMD of leaves [109]. This result supports the conclusion that the complete feruloylarabinoxylan complex is synthesized in the Golgi and exported to the apoplast [110].

An important difference between grasses and legumes is that while tissues in legumes with thick lignified walls can be only marginally digested by rumen microbes, similar thick lignified walls of grass tissues are extensively degraded, albeit slowly [9,12]. The reason for this disparity has not been adequately explained. Interestingly, more grass lignin is soluble in acid detergent than observed for legumes and grass lignin has $p$-coumarate esters attached to syringyl-lignin units [20,111]. $p$-Coumaric acid appears to be esterified to sinapyl alcohol prior to incorporation of the conjugate into lignin, and these $p$-coumarate esters act as terminal pendant groups on grass lignin because the $p$-coumarates do not react with additional monolignols to extend the polymer [112]. This suggests that $p$-coumarate esters limit the size of grass lignins and perhaps these smaller lignin polymers are less protective of polysaccharides from enzymatic digestion. Smaller lignin polymers should be more soluble in acid detergent, in agreement with the observation that grasses contain more acid detergent soluble lignin [20]. Alfalfa normally accumulates syringyl-rich lignin in vascular tissues as these tissues mature, but this syringyl lignin does not include $p$-coumarate esters [13]. A transferase attaches $p$ coumaric acid to monolignols [113]. Transforming the $p$-coumaryl transferase gene into alfalfa should result in the inclusion of $p$ coumarate esters of syringyl lignin that result in smaller lignin polymers which are less inhibitory of cell wall digestion. Downregulation of $\mathrm{C} 3 \mathrm{H}$ and $\mathrm{HCT}$ results in a large increase in usually rare hydroxyphenyl-lignin units and a small reduction in molecular weight of extractable lignin [114]. Because these transformants have significantly less lignin it was not possible to determine whether the reduction in lignin polymer size was responsible for the increased digestibility.

\subsection{Gene expression}

Transgene constructs used for modifying lignin in alfalfa have used either the cauliflower mosaic virus (CaMV) 35S promoter [48] or the bean (Phaseolus vulgaris L.) phenylalanine ammonia-lyase 2 (PAL2) promoter [49-52]. Neither promoter is ideal for manipulating target genes to increase forage digestion. The $35 \mathrm{~S}$ promoter is not a strong promoter in alfalfa compared to other constitutive promoters [115] and expression occurs in multiple organs. In stems, expression of genes driven by the $35 \mathrm{~S}$ promoter is observed in the epidermis, cortex, phloem, fascicular and interfascicular cambium, and protoxylem. The PAL2 promoter is active in primary xylem of alfalfa stems and petioles and in epidermal cells [50,82]. It is likely that activity occurs in roots, as has been seen in transgenic tobacco [116], and because the alfalfa PAL gene is strongly expressed in roots [117]. The impact of reducing lignin in alfalfa roots has not been investigated but could impact plant productivity. Also, expression is likely in flowers because down-regulation of $\mathrm{C} 4 \mathrm{H}$ driven by the PAL2 promoter results in loss of anthocyanin in alfalfa flower petals [52]. The promoter may also be induced by pathogens, similar to the alfalfa PAL gene [118], which could impact a plant's ability to construct lignified barriers to pathogen invasion. Some alfalfa gene promoters are active in xylem, including a truncated promoter from a phospho-enolpyruvate carboyxlase gene [119] and the promoter from a mitogen-activated protein kinase gene [120], but their expression is not limited to xylem or to stems, which is a drawback.

The ideal alfalfa promoter for lignin reduction/modification would be expressed only in secondary xylem, which is the most recalcitrant tissue to digestion by rumen microorganisms. It would also have stable expression in different genetic backgrounds and environments. Strategies for identifying a promoter for secondary xylem expression include transcriptional profiling from isolated secondary xylem cells [121] or comparative transcriptome profiling between stems in which primary and secondary development is occurring [122,123]. In Arabidopsis the latter approach resulted in identification of a promoter from a NAC family transcription factor that is specific to secondary xylem in stems and roots [124]. Xylem is composed of secondary thickened tracheary elements and fibers, and non-thickened parenchyma. Reducing or eliminating lignin in fibers may be one means of increasing digestibility without negative effects on productivity, as suggested by research in tobacco [84]. Because cell-specific gene expression patterns have been observed in vascular tissue [122,125], it should be possible to identify gene promoters with specific or enhanced expression in xylem fibers to manipulate expression of target genes.

For the most part, attempts to alter lignin content or composition have focused on altering expression of single genes, primarily those involved in monolignol biosynthesis. However, coordinate down-regulation of more than one gene may be needed to minimize metabolic imbalances. Simply crossing two transgenic plants down-regulated for two different lignin biosynthetic genes resulted in unexpected phenotypes in the progeny [126]. In plants for which enzyme activity had returned to levels seen in controls, the authors speculated that expression of the transgenes were suppressed by the wild-type copies or due to use of two $35 \mathrm{~S}$ promoter sequences. Also, making crosses with transgenic alfalfa in which transgenes are inserted into the same genetic background, will lead to severe in-breeding depression. An alternative approach to crossing or retransformation is the use of a chimeric gene for down-regulation in which the transgene is composed of sequences of two or more target genes using a co-suppression or RNAi approach [127]. This approach was used successfully to down-regulate three lignin biosynthesis genes in tobacco [126] and warrants testing in forage crops.

An alternative means of modifying expression of multiple genes is through altering expression of a regulatory transcription factor. Recent progress in identifying key transcription factors in Arabidopsis and woody species should be extended to forage crops. Regulation of secondary wall synthesis occurs at multiple levels in Arabidopsis $[44,128]$; however, our current understanding is incomplete, as regulation probably occurs at the cellular and subcellular levels that results in the diverse lignification patterns in secondary xylem. Transcription factors in the NAC family regulate secondary wall developmental programming in stems. Lignification in interfascicular and xylem fiber cells is lacking in transformants in 
which both NST1 and NST3 are disrupted, or when their expression is repressed by RNAi $[129,130]$. This severe reduction in lignin results in procumbent stems with dramatically reduced stem tensile strength. Additionally, a NAC transcript factor, ANAC012, negatively regulates secondary cell wall deposition in xylem fibers. Ectopic over-expression resulted in suppressed cell wall thickening and lignification [124]. In Arabidopsis, NST3 regulates MYB family transcription factors, which in turn regulate expression of lignin biosynthetic genes $[44,128]$. These regulatory genes are potential targets for expression modification to reduce lignification. Shen et al. [131] have identified, cloned and characterized a switchgrass R2R3 MYB factor that appears to control parts of the lignin biosynthesis pathway. Down-regulation of this gene in switchgrass was accompanied by lower lignin content, changes in $p$-coumarate-toferulate ratios, and simultaneous improvements in saccharification of biomass. However, practical application of transcription factors will require balancing expression to improve forage digestibility without sacrificing plant structure, possibly through cell-specific expression or developmentally regulated expression.

In addition to transcriptional regulation, transcription factors are subject to complex post-transcriptional and post-translational regulation [132]. Transcript levels of a transcription factor involved in xylem development can be modified by expression of a micro RNA, miR166, in Arabidopsis and poplar [133,134]. Micro RNA regulation is a pervasive mechanism of gene regulation but this facet of secondary cell wall development has yet to be explored in forage species and may provide additional targets for genetic manipulation for improving forage digestibility. A recent report by Chuck et al. [135] indicated that over-expression of the maize Corngrass1 miRNA in switchgrass leads to interesting developmental outcomes including a juvenile habit, increased accumulation of starch, greater leafiness, and suppression of flowering. Switchgrass plant parts, especially leaves, were more readily saccharified; however, stronger down-regulation of the target genes was accompanied by growth and yield penalties. In Arabidopsis and other plants, groups of interacting transcription factors appear to control secondary cell wall development [129,136-138]. Understanding how these transcription factors affect quality parameters in forages will be challenging.

Studies using grass promoters that affect cell walls in grasses have been few, probably due to the difficulty of transforming forage grasses and the availability of the brown midrib mutants. However this is likely to change in the future with the sequencing of the maize and sorghum genomes $[139,140]$ and identification of transcription factor orthologs that impact secondary cell wall development in switchgrass [141]. Fornale and associates [142-144] have studied MYB factors (ZmMYB31 and ZmMYB42) that impact lignification in maize and when transgenically overexpressed in Arabidopsis [143]. Over-expression of ZmMYB42 in Arabidopsis reduced transcripts for genes involved in lignin biosynthesis, lowered lignin levels, and improved the digestibility of cell walls from transgenic plants [144]. Specifically, maize MYB31 down-regulated genes involved in lignin biosynthesis, as observed earlier for ZmMYB42, and changed the flux of carbon from lignin synthesis to anthocyanin synthesis [142]. However, plants overexpressing this gene showed a dwarf phenotype and its overall utility in improving digestibility of grasses is unknown.

\subsection{Tissues and development}

Much of the observed variation for rumen digestibility of roughages probably results from differences in cell wall development of tissues and the relative proportions of tissue types among genotypes rather than a change in average composition of cell walls between genotypes. Alfalfa has significant within cultivar variability in tissue proportions related to IVDMD potential $[13,145]$.
Smooth bromegrass lines selected for high IVDMD had greater proportions of non-lignified tissues [146]. A comparison of the stem anatomy among switchgrass plants selected for divergent IVDMD showed that there were significant changes in lignified tissue distribution [147]. Most frequently, there was extensive lignification of the cortical sclerenchyma and parenchyma in switchgrass plants with low digestibility as compared to plants from the higher IVDMD population. A collection of these plants also showed differential accessibility by cellulases, indicating that there were differences in cell wall architecture in addition to wall composition [148]. In most cases we can expect that differential expression of transcription factors could be responsible for these changes.

Phloem fibers in alfalfa stems have unusual cell wall development patterns [149]. This tissue develops a thick primary wall that is rich in pectin and also a thick secondary wall rich in cellulose. Only a thin ring of lignin is deposited in the cell lumen edge of the thickened primary wall. All of the non-lignified cellulose-rich secondary walls are digested by rumen microbes and all of the thick primary walls are digested except for the lumen-side edge leaving non-digested, thin lignified wall structures (Fig. 2) [13,149]. Some xylem fiber cells in alfalfa stems develop a thick, non-lignified wall region on the cell lumen side of the thick, lignified secondary wall present in xylem fiber cells [13]. While the lignified secondary walls were only marginally digested by rumen microbes, the additional non-lignified interior wall regions were completely digested if the cells were ruptured [11]. These are two examples of unique, tissuespecific cell wall structures that result in greater digestibility. If either of these wall development patterns could be expressed by other tissues, it may be possible to increase the overall digestibility of alfalfa and other roughages.

The pith of grass and legume stems is filled with parenchyma tissue when the plants are immature, but in most crops this pith parenchyma senesces and the stems become hollow. Annual $\mathrm{C}_{4}$ grasses such as maize and sorghum are an exception to this rule as they retain living pith parenchyma until grain maturity. Pith parenchyma cells in these grasses undergo minimal wall thickening and generally become lignified during maturation, although more slowly than the thick-walled rind parenchyma and other tissues [14]. As a result, pith parenchyma remains relatively more digestible than rind tissues even at advanced maturity. Alfalfa plants occasionally retain intact pith parenchyma in stems and the walls thicken slightly and lignify [13]. However, lignification begins in those parenchyma cells closest to the xylem and slowly extends towards the center of the stem. As a result, alfalfa pith parenchyma remains partially digestible for a longer duration during plant development. If roughage species that normally do not retain pith parenchyma tissue at advanced maturity stages could be re-programmed to avoid pith parenchyma senescence, then overall cell wall digestibility of the crop would be enhanced even if lignification was not altered. The impact of such a dramatic shift in plant development on plant fitness cannot be predicted.

\section{Biofuel production}

Production of biofuels requires that cell wall polysaccharides be hydrolyzed to free sugars that can be fermented to alcohols. Several processes have been proposed and most include a pretreatment to increase accessibility to cellulose by hydrolytic enzymes [150]. It is the harsh physical, chemical, and/or thermal pretreatment that most differentiates biofuel conversion processes from rumen digestion. One of the most mature of these biofuel processes utilizes dilute acid/high temperature to remove non-cellulosic polysaccharides and modify the lignin in biomass by acid hydrolysis. Cell wall polysaccharide hydrolysis by this high temperature/acid pretreatment and enzymatic saccharification process was reported to be 
negatively correlated with biomass lignin concentration similarly to that observed for rumen digestion [3]. However, correlations of lignification traits (Klason lignin concentration, $p$-coumarates esters, ferulate esters and ethers) with polysaccharide hydrolysis in the conversion process for maize stover did not match correlations found for rumen digestibility of the polysaccharides [151]. This lack of correspondence is not surprising because the pretreatment process drastically modifies cell wall structure and composition prior to the enzymatic hydrolysis. Certainly reduced lignification should improve the yield of fermentable sugars from biomass for biofuel production [54,81], but relationships between rumen digestibility and lignification cannot be relied upon to correctly identify useful targets for genetic modification. A key feature in the conversion of lignocellulosic biomass is the accessibility of cellulose to cellulases post pretreatment [152-154]. Because this is an outcome from the complex relationship between biomass composition and chemical pretreatment, it is likely that breeding for improved biomass quality for conversion to fuels will need different targets as compared to improving ruminant digestibility.

Presently, biofuel conversion of hexose-containing polymers (cellulose) can be accomplished more readily than from hemicelluloses and pectins which contain pentose and other non-hexose sugars. Therefore, increasing cellulose content was the focus of several studies. Cellulose increased in a compensatory fashion in some species by decreasing lignin content via down-regulation of $4 \mathrm{CL}$ [74,75], although whether this phenotype will be retained under field conditions is not clear [155]. Cellulose content and soluble carbohydrates were increased in hybrid poplar by over-expression of a sucrose synthase (SuSy) gene from cotton (Gossypium hirsutum L.) without negative phenotypic changes to the plants [156]. There are no reports of the effect of SuSy over-expression in herbaceous plants and this approach warrants further investigation for bioenergy crops.

It has been suggested that increasing the ratio of water soluble polysaccharides to cellulose in cells walls or modifying side chain constituents of hemicellulose to decrease hydrogen bonding with cellulose may make walls more susceptible to hydrolysis [157]. One strategy to modify composition of hemicelluloses is to up- or down-regulate expression of glycosyltransferases and glycan synthases. However, this approach has had mixed results, most likely because there are isoform-specific properties in each gene family and due to a lack of understanding of the pleotrophic effects of altering expression of a single gene $[158,159]$. There are indications that modifying expression of several genes simultaneously may produce the desired phenotype. Arabidopsis xylotransferase double mutant plants lack xyloglucan but grow and develop fairly normally [160]. Modifying cell wall composition in such a complex and dynamic system will require more information on specific gene expression patterns and enzyme activities. Transgene regulation control by a tissue-specific promoter or promoter induction during specific growth stages appears critical to avoid compromising vascular cell integrity and plant development [74,75].

Alterations to S/G monolignol ratios could have a stronger influence in the conversion of biomass to biofuels as compared to roughage digestibility in ruminants. The expectation is that lignin composed of more syringyl units will be more effectively removed by pretreatments as is the case for pulping hardwoods (mixed syringyl/guaiacyl lignin) vs. softwoods (guaiacyl only lignin) [46]. This appears to be true for a number of woody species in which increased S/G ratios were correlated to ethanol yields [161,162]. Data from herbaceous species is less clear. For example, biomass obtained from field grown brown midrib sorghum with CAD (bmr6) or COMT (bmr12) alleles exhibited similar conversion efficiencies into ethanol although their S/G ratios were different [163]. In switchgrass plants divergently bred for IVDMD there was no apparent correlation between S/G ratios and ethanol yields [164].
Transgenic switchgrass plants with reductions in CAD [165,166], COMT [41], and 4CL [167] activities all display lower lignin concentrations and improved conversion to ethanol. As anticipated, COMT down-regulated switchgrass lines had lowered levels of syringyl units, and displayed significantly greater conversion to ethanol [41]. However, in none of these studies could the impact of altered $S / G$ ratio be separated from simultaneous changes in lignin concentration. Until such non-confounded data are available, the actual impact of S/G monolignol ratio on biofuel conversion will remain unresolved.

Novel monolignol units could be incorporated into lignin to produce plants that are more efficiently converted to biofuels (Fig. 1) [112]. Hydroxycinnamates such as ferulic acid can form conjugates with monolignols and these conjugates are incorporated into dehydrogenation polymer lignins in vitro through free-radical reactions. Lignins that include hydroxycinnamate esters can be easily depolymerized using alkali as part of a pretreatment process [112] Such a process would be useful for biofuels; however, unless the cost of alkali pretreatment drops substantially these types of lignin modifications would have no use in animal feeding. The alkaline and acidic pretreatments envisioned for biofuel conversion systems would negate the benefits of the low ferulate sfe maize mutant discussed earlier because the pretreatments would cleave the ester portion of the lignin/arabinoxylan cross link or hydrolyze the arabinoxylan to free sugars, respectively. But low lignin brown midrib sorghum has greater conversion efficiency than wild-type sorghum [163].

\section{Conclusions}

It has been estimated that over 750 genes could impact plant cell wall synthesis [168]. The bulk of these genes code for various families of proteins involved in polysaccharide biosynthesis and deposition. In contrast, lignin biosynthesis is catalyzed by a smaller number of genes, and typically only one, or at most a few genes within a related gene family actually impact lignin content. These genes have been extensively studied in model systems, and the key genes involved in lignification have been identified in many plants. Therefore, it has been easier to manipulate cell wall lignin content rather than cell wall polysaccharides. Improved cell wall digestibility has been associated with low lignin transgenic plants, but the impact appears to be primarily the result of reduced lignin concentration rather than altered lignin composition. The presence of a diversity of tissues within each plant organ suggests that continued improvement in digestibility of roughages will require greater knowledge of the transcriptional control of tissue distribution within plant organs, and cell wall composition and architecture. Such improvements will also have to maintain inherent plant traits for survival, yield, and stress resistance.

\section{References}

[1] H.G. Jung, D.A. Deetz, Cell wall lignification and degradability, in: H.G. Jung, D.R. Buxton, R.D. Hatfield, et al. (Eds.), Forage Cell Wall Structure and Digestibility, ASA-CSSA-SSSA, Madison, WI, 1993, pp. 315-346.

[2] P.J. Van Soest, Nutritional Ecology of the Ruminant, second ed., Cornell University, Ithaca, NY, 1994, 528 pp.

[3] B.S. Dien, H.G. Jung, K.P. Vogel, et al., Chemical composition and response to dilute-acid pretreatment and enzymatic saccharification of alfalfa, reed canarygrass, and switchgrass, Biomass Bioenergy 30 (2006) 880-891.

[4] L.L. Berger, G.C. Fahey Jr., L.D. Bourquin, et al., Modification of forage quality after harvest, in: G.C. Fahey Jr., M. Collins, D.R. Mertens, et al. (Eds.), Forage Quality, Evaluation, and Utilization, ASA-CSSA-SSSA, Madison, WI, 1994, pp. 922-966.

[5] M.D. Casler, K.P. Vogel, Accomplishments and impact from breeding for increased forage nutritional value, Crop Sci. 39 (1999) 12-20.

[6] R.A. Dixon, C.J. Lamb, S. Masoud, et al., Metabolic engineering: prospects for crop improvement through the genetic manipulation of phenylpropanoid biosynthesis and defense response - a review, Gene 179 (1996) 61-71. 
[7] M.B. Sticklen, Feedstock crop genetic engineering for alcohol fuels, Crop Sci. 47 (2007) 2238-2248.

[8] P.J. Weimer, Why don't ruminal bacteria digest cellulose faster? J. Dairy Sci. 79 (1996) 1496-1502.

[9] F.M. Engels, Some properties of cell wall layers determining ruminant digestion, in: A. Chesson, E.R. Orskov (Eds.), Physico-Chemical Characterization of Plant Residues for Industrial and Feed Use, Elsevier Applied Science, London, 1989, pp. 80-87.

[10] J.R. Wilson, D.R. Mertens, Cell wall accessibility and cell structure limitations to microbial digestion of forage, Crop Sci. 35 (1995) 251-259.

[11] F.M. Engels, H.G. Jung, Alfalfa stem tissues: impact of lignification and cell length on ruminal degradation of large particles, Anim. Feed Sci. Technol. 120 (2005) 309-321.

[12] H.G. Jung, F.M. Engels, Alfalfa stem tissues: rate and extent of cell-wall thinning during ruminal degradation, Neth. J. Agric. Sci. 49 (2001) 3-13.

[13] H.G. Jung, F.M. Engels, Alfalfa stem tissues: cell-wall deposition, composition, and degradability, Crop Sci. 42 (2002) 524-534.

[14] H.G. Jung, M.D. Casler, Maize stem tissues: cell wall concentration and composition during development, Crop Sci. 46 (2006) 1793-1800.

[15] R.D. Hatfield, P.J. Weimer, Degradation characteristics of isolated and in situ cell wall lucerne pectic polysaccharides by mixed ruminal microbes, J. Sci. Food Agric. 69 (1995) 185-196.

[16] H.G. Jung, M.D. Casler, Maize stem tissues: impact of development on cell wall degradability, Crop Sci. 46 (2006) 1801-1809.

[17] O. Theander, E. Westerlund, Quantitative analysis of cell wall components, in : H.G. Jung, D.R. Buxton, R.D. Hatfield, al. et (Eds.), Forage Cell Wall Structure and Digestibility, ASA-CSSA-SSSA, Madison, WI, 1993, pp. 83-104.

[18] R.D. Hatfield, H.G. Jung, J. Ralph, et al., A comparison of the insoluble residue produced by the Klason lignin and acid detergent lignin procedures, J. Sci. Food Agric. 65 (1994) 51-58.

[19] H.G. Jung, V.H. Varel, P.J. Weimer, et al., Accuracy of Klason lignin and acid detergent lignin methods as assessed by bomb calorimetry, J. Agric. Food Chem. 47 (1999) 2005-2008

[20] J.B. Lowry, L.L. Conlan, A.C. Schlink, et al., Acid detergent dispersible lignin in tropical grasses, J. Sci. Food Agric. 65 (1994) 41-49.

[21] M.D. Casler, Phenotypic recurrent selection methodology for reducing fiber concentration in smooth bromegrass, Crop Sci. 39 (1999) 381-390.

[22] A. Claessens, R. Michaud, G. Belanger, et al., Characteristics of timothy genotypes divergently selected for fiber traits, Crop Sci. 44 (2004) 81-88.

[23] D.P. Wolf, J.G. Coors, K.A. Albrecht, et al., Forage quality of maize genotype selected for extreme fiber concentrations, Crop Sci. 33 (1993) 1353-1359.

[24] J.G. Coors, C.C. Lowe, R.P. Murphy, Selection for improved nutritional quality of alfalfa forage, Crop Sci. 26 (1986) 843-848.

[25] K.D. Kephart, D.R. Buxton, R.R. Hill Jr., Digestibility and cell-wall components of alfalfa following selection for divergent herbage lignin concentration, Crop Sci. 30 (1990) 207-212.

[26] I.Y. Tecle, D.R. Viands, J.L. Hansen, et al., Response from selection for pectin concentration and indirect response in digestibility of alfalfa, Crop Sci. 46 (2006) 1081-1087.

[27] M.D. Casler, R.D. Hatfield, Cell wall composition of smooth bromegrass plants selected for divergent fiber concentration, J. Agric. Food Chem. 54 (2006) 8206-8211.

[28] Y. Barriére, C. Guillet, D. Goffner, et al., Genetic variation and breeding strategies for improved cell wall digestibility in annual forage crops. A review, Anim. Res. 52 (2003) 193-228.

[29] A.J. Cardinal, M. Lee, K.J. Moore, Genetic mapping and analysis of quantitative trait loci affecting fiber and lignin content in maize, Theor. Appl. Genet. 106 (2003) 866-874

[30] M.D. Krakowsky, M. Lee, J.G. Coors, Quantitative trait loci for cell wall components in recombinant inbred lines of maize (Zea mays L.): stalk tissue, Theor. Appl. Genet. 111 (2005) 337-346.

[31] M.D. Krakowsky, M. Lee, J.G. Coors, Quantitative trait loci for cell wall components in recombinant inbred lines of maize (Zea mays L.): leaf sheath tissue, Theor. Appl. Genet. 112 (2006) 717-726.

[32] S.C. Murray, W.L. Rooney, S.E. Mitchell, et al., Genetic improvement of sorghum as a biofuel feedstock: II. QTL for stem and leaf structural carbohydrates, Crop Sci. 48 (2008) 2180-2193.

[33] A.L. Shiringani, W. Friedt, QTL for fibre-related traits in grain $\times$ sweet sorghum as a tool for the enhancement of sorghum as a biomass crop, Theor. Appl. Genet. (2011), http://www.springerlink.com/openurl. asp?genre=article\&id=DOI 10.1007/s00122-011-1642-4.

[34] V. Méchin, O. Argillier, Y. Hebert, et al., Genetic analysis and QTL mapping of cell wall digestibility and lignification in silage maize, Crop Sci. 41 (2001) 690-697.

[35] Y. Barriére, A. Laperche, L. Barrot, et al., QTL analysis of lignification and cell wall digestibility in the Bay- $0 \times$ Shahdara RIL progeny of Arabidopsis thaliana as a model system for forage plant, Plant Sci. 168 (2005) 1235-1245.

[36] R.E. Lorenzana, M.F. Lewis, H.G. Jung, et al., Quantitative trait loci and trait correlations for maize stover cell wall composition and glucose release for cellulosic ethanol, Crop Sci. 50 (2010) 541-555.

[37] S.P. Hazen, M. Hawley, G.L. Davis, et al., Quantitative trait loci and comparative genomics of cereal cell wall composition, Plant Physiol. 132 (2003) 263-271.

[38] S.K. Stombaugh, J.H. Orf, H.G. Jung, et al., Quantitative trait loci associated with cell wall polysaccharides in soybean seed, Crop Sci. 44 (2004) 2101-2106.
[39] W. Boerjan, J. Ralph, M. Baucher, Lignin biosynthesis, Annu. Rev. Plant Biol 54 (2003) 519-546

[40] L.L. Escamilla-Trevino, H. Shen, S.R. Uppalapati, et al., Switchgrass (Panicum virgatum) possesses a divergent family of cinnamoyl CoA reductases with distinct biochemical properties, New Phytol. 185 (2010) 143-155.

[41] C. Fu, J.R. Mielenz, X. Xiao, et al., Genetic manipulation of lignin reduces recalcitrance and improves ethanol production from switchgrass, Proc. Natl. Acad. Sci. U. S. A. 108 (2011) 3803-3808.

[42] Y. Lee, F. Chen, L. Gallego-Giraldo, et al., Integrative analysis of transgenic alfalfa (Medicago sativa L.) suggests new metabolic control mechanisms for monolignol biosynthesis, PLoS Comput. Biol. 7 (5) (2011) e1002047, doi:10.1371/journal.pcbi.1002047.

[43] N.A. Palmer, S.E. Sattler, A.J. Saathoff, et al., Genetic background impacts soluble and cell wall-bound aromatics in brown midrib mutants of sorghum, Planta 229 (2008) 115-127.

[44] Q. Zhao, R.A. Dixon, Transcriptional networks for lignin biosynthesis: more complex than we thought? Trends Plant Sci. 16 (2011) 227-233.

[45] M. Baucher, B. Monties, M. Van Montagu, et al., Biosynthesis and genetic engineering of lignin, Crit. Rev. Plant Sci. 17 (1998) 125-197.

[46] M. Baucher, C. Halpin, M. Petit-Conil, et al., Biosynthesis and genetic engineering of lignin, Crit. Rev. Plant Sci. 38 (2003) 305-350.

[47] R. Vanholme, K. Morreel, J. Ralph, et al., Lignin engineering, Curr. Opin. Plant Biol. 11 (2008) 278-285.

[48] M. Baucher, M.A. Bernard-Vailhe, B. Chabbert, et al., Down-regulation of cinnamyl alcohol dehydrogenase in transgenic alfalfa (Medicago sativa L.) and the effect on lignin composition and digestibility, Plant Mol. Biol. 39 (1999) 437-447

[49] F. Chen, M.S.S. Reedy, S. Temple, et al., Multi-site genetic modulation of monolignol biosynthesis suggestions new routes for formation of syringyl lignin and wall-bound ferulic acid in alfalfa (Medicago sativa L.), Plant J. 48 (2006) 113-124.

[50] D. Guo, F. Chen, K. Inoue, et al., Downregulation of caffeic acid 3-O methyltransferase and caffeoyl $\mathrm{CoA} 3-\mathrm{O}$-methyltransferase in transgenic alfalfa: impacts on lignin structure and implications for the biosynthesis of $G$ and S lignin, Plant Cell 13 (2001) 73-88.

[51] L.A. Jackson, G.L. Shadle, R. Zhou, et al., Improving saccharification efficiency of alfalfa stems through modification of the terminal stages of monolignol biosynthesis, Bioenergy Res. 1 (2008) 180-192.

[52] M.S. Reddy, F. Chen, G. Shadle, et al., Targeted down-regulation of cytochrome P450 enzymes for forage quality improvement in alfalfa (Medicago sativa L.), Proc. Natl. Acad. Sci. U. S. A. 102 (2005) 16573-16578.

[53] D. Guo, F. Chen, J. Wheeler, et al., Improvement of in-rumen digestibility of alfalfa forage by genetic manipulation of lignin $O$-methyltransferases, Transgenic Res. 10 (2001) 457-464

[54] F. Chen, R.A. Dixon, Lignin modification improves fermentable sugar yields for biofuel production, Nat. Biotechnol. 25 (2007) 759-761.

[55] V.J.H. Sewalt, W. Ni, H.G. Jung, et al., Lignin impact on fiber degradation: increased enzymatic digestibility of genetically engineered tobacco (Nicotiana tabacum) stems reduced in lignin content, J. Agric. Food Chem. 45 (1997) 1977-1983.

[56] T. Goujon, V. Ferret, I. Mila, et al., Down-regulation of the AtCCR1 gene in Arabidopsis thaliana: effects on phenotype, lignins and cell wall degradability, Planta 217 (2003) 218-228.

[57] D.R. Mertens, M. McCaslin, Evaluation of alfalfa hays with down-regulated lignin biosynthesis, J. Dairy Sci. 91 (Suppl. 1) (2008) 170.

[58] D. Weakley, D.R. Mertens, M. McCaslin, Lactating cow responses to alfalfa hays with down-regulated lignin biosynthesis, J. Dairy Sci. 91 (Suppl. 1) (2008) 170

[59] J.H. Cherney, D.J.R. Cherney, D.E. Akin, et al., Potential of brown-midrib, lowlignin mutants for improving forage quality, Adv. Agron. 46 (1991) 157-198.

[60] M. Oba, M.S. Allen, Effects of brown midrib 3 mutation in corn silage on dry matter intake and productivity of high yielding dairy cows, J. Dairy Sci. 82 (1999) 135-142.

[61] A.L. Oliver, R.J. Grant, J.F. Pedersen, et al., Comparison of brown midrib-6 and -18 forage sorghum with conventional sorghum and corn silage in diets of lactating dairy cows, J. Dairy Sci. 87 (2004) 637-644.

[62] S.E. Sattler, A.J. Saathoff, E.J. Haas, et al., A nonsense mutation in a cinnamy alcohol dehydrogenase gene is responsible for the Sorghum brown midrib6 phenotype, Plant Physiol. 150 (2009) 584-595.

[63] K. Zhang, Q. Qian, Z. Huang, et al., GOLD HULL AND INTERNODE2 encodes a primarily multifunctional cinnamyl-alcohol dehydrogenase in rice, Plant Physiol. 140 (2006) 972-983.

[64] J. Piquemal, S. Chamayou, I. Nadaud, et al., Down-regulation of caffeic acid $O$-methyltransferase in maize revisited using a transgenic approach, Plant Physiol. 130 (2002) 1675-1685.

[65] X. He, M.B. Hall, M. Gallo-Meagher, et al., Improvement of forage quality by downregulation of maize O-methyltransferase, Crop Sci. 43 (2003) 2240-2251.

[66] S. Guillaumie, D. Goffner, O. Barbier, et al., Expression of cell wall related genes in basal and ear internodes of silking brown-midrib-3, caffeic acid $O$ methyltransferase (COMT) down-regulated, and normal maize plants, BMC Plant Biol. 8 (2008) 71.

[67] F. Vignols, J. Rigau, M.A. Torres, et al., The brown midrib (bm3) mutation in maize occurs in the gene encoding caffeic acid $O$-methyltransferase, Plant Cell 7 (1995) 407-416.

[68] L. Chen, C. Auh, F. Chen, et al., Lignin deposition and associated changes in anatomy, enzyme activity, gene expression, and ruminal degradability in 
stems of tall fescue at different developmental stages, J. Agric. Food Chem. 50 (2002) 5558-5565.

[69] L. Chen, C.K. Auh, P. Dowling, et al., Improved forage digestibility of tall fescue (Festuca arundinacea) by transgenic down-regulation of cinnamyl alcohol dehydrogenase, Plant Biotechnol. J. 1 (2003) 437-449.

[70] L. Chen, C.K. Auh, P. Dowling, et al., Transgenic down-regulation of caffeic acid $O$-methyltransferase (COMT) led to improved digestibility in tall fescue (Festuca arundinacea), Funct. Plant Biol. 31 (2004) 235-245.

[71] N.C. Carpita, Update on mechanisms of plant cell wall biosynthesis: how plants make cellulose and other $(1 \rightarrow 4)-\beta$-D-glucans, Plant Physiol. 155 (2011) 171-184.

[72] D.A. Samac, L. Litterer, G. Temple, et al., Expression of UDP-glucose dehydrogenase reduces cell-wall polysaccharide concentration and increases xylose content in alfalfa stems, Appl. Biochem. Biotechnol. 116 (2004) 1167-1182.

[73] J. Rösti, C.J. Barton, S. Albrecht, et al., UDP-glucose 4-epimerase isoforms UGE2 and UGE4 cooperate in providing UDP-galactose for cell wall biosynthesis and growth in Arabidopsis thaliana, Plant Cell 19 (2007) 1565-1579.

[74] L. Li, Y. Zhou, X. Cheng, J. Sun, J.M. Marita, J. Ralph, V.L. Chiang, Combinatorial modification of multiple lignin traits in trees through multigene cotransformation, Proc. Natl. Acad. Sci. U. S. A. 100 (2003) 4939-4944.

[75] J. Yang, F. Chen, O. Yu, R.N. Beachy, Controlled silencing of 4-coumarate:CoA ligase alters lignocellulose composition without affecting stem growth, Plant Physiol. Biochem. 49 (2011) 103-109.

[76] H. Hoenicka, S. Lautner, A. Klingberg, et al., Influence of over-expression of the FLOWERING PROMOTING FACTOR 1 gene (FPF1) from Arabidopsis on wood formation in hybrid popular (Populus tremula L. $\times$ P. tremuloides Michx.), Planta (2011), doi:10.1007/s00425-011-1507-8.

[77] J.F. Pedersen, K.P.Vogel, D.L. Funnell, Impact of reduced lignin on plant fitness, Crop Sci. 45 (2005) 812-819.

[78] M.D. Casler, D.R. Buxton, K.P. Vogel, Genetic modification of lignin concentration affects fitness of perennial herbaceous plants, Theor. Appl. Genet. 104 (2002) 127-131.

[79] K.P. Vogel, A.A. Hopkins, K.J. Moore, et al., Winter survival in switchgrass populations bred for high IVDMD, Crop Sci. 42 (2002) 1857-1862.

[80] M. Chabannes, A. Barakate, C. Lapierre, et al., Strong decrease in lignin content without significant alteration of plant development is induced by simultaneous down-regulation of cinnamoyl CoA reductase (CCR) and cinnamyl alcohol dehydrogenase (CAD) in tobacco plants, Plant J. 28 (2001) 257-270.

[81] G. Shadle, F. Chen, M.S.S. Reddy, et al., Down-regulation of hydroxycinnamoyl CoA: shikimate hydroxycinnamoyl transferase in transgenic alfalfa affects lignification, development and forage quality, Phytochemistry 68 (2007) 1521-1529.

[82] J. Nakashima, F. Chen, L. Jackson, et al., Multi-site genetic modification of monolignol biosynthesis in alfalfa (Medicago sativa): effects on lignin composition in specific cells, New Phytol. 179 (2008) 738-750.

[83] L. Gallego-Giraldo, Y. Jikumaru, Y. Kamiya, et al., Selective downregulation leads to constitutive defense response expression in alfalfa (Medicago sativa L.), New Phytol. 190 (2011) 627-639.

[84] M. Chabannes, K. Ruel, A. Yoshinaga, et al., In situ analysis of lignins in transgenic tobacco reveals a differential impact of individual transformation on the spatial patterns of lignin deposition at the cellular and subcellular levels, Plant J. 28 (2001) 271-282.

[85] J.H. Grabber, D.R. Mertens, H. Kim, et al., Cell wall fermentation kinetics are impacted more by lignin content and ferulate cross-linking than by lignin composition, J. Sci. Food Agric. 89 (2009) 122-129.

[86] H.G.Jung, W. Ni, C.C.S. Chapple, et al., Impact of lignin composition on cell-wall degradability in an Arabidopsis mutant, J. Sci. Food Agric. 79 (1999) 922-928.

[87] J.H. Grabber, P.F. Schatz, H. Kim, et al., Identifying new lignin bioengineering targets: 1. Monolignol-substitute impacts on lignin formation and cell wall fermentability, BMC Plant Biol. 10 (2010) 114.

[88] J.H. Grabber, J. Ralph, R.D. Hatfield, Severe inhibition of maize wall degradation by synthetic lignins formed with coniferaldehyde, J. Sci. Food Agric. 78 (1998) 81-87.

[89] J. Ralph, C. Lapierre, J.M. Marita, et al., Elucidation of new structures in lignins of CAD-and COMT-deficient plants by NMR, Phytochemistry 57 (2001) 993-1003.

[90] J. Gressel, Y. Vered, S. Bar-Lev, et al., Partial suppression of cellulase action by artificial lignification of cellulose, Plant Sci. Lett. 32 (1983) 349-353.

[91] H.G. Jung, J. Ralph, Phenolic-carbohydrate complexes in plant cell walls and their effect on lignocellulose utilization, in: D.E. Akin, L.G. Ljundahl, J.R. Wilson, et al. (Eds.), Microbial and Plant Opportunities to Improve Lignocellulose Utilization by Ruminants, Elsevier, New York, 1990, pp. 173-182.

[92] J.H. Grabber, R.D. Hatfield, J. Ralph, et al., Ferulate cross-linking in cell walls isolated from maize cell suspensions, Phytochemistry 40 (1995) 1077-1082.

[93] T.B.T. Lam, K. Iiyama, B.A. Stone, Cinnamic acid bridges between cell wall polymers in wheat and phalaris internodes, Phytochemistry 31 (1992)1179-1183.

[94] J. Ralph, J.H. Grabber, R.D. Hatfield, Lignin-ferulate cross-links in grasses: active incorporation of ferulate polysaccharide esters into ryegrass lignins, Carbohydr. Res. 275 (1995) 167-178.

[95] J.H. Grabber, How do lignin composition, structure, and cross-linking affect degradability? A review of cell wall model studies, Crop Sci. 45 (2005) 820-831.

[96] J.H. Grabber, J. Ralph, R.D. Hatfield, Ferulate cross-links limit the enzymatic degradation of synthetically lignified primary walls of maize, J. Agric. Food Chem. 46 (1998) 2609-2614.
[97] J.H. Grabber, J. Ralph, R.D. Hatfield, et al., Dehydrogenation polymer-cell wal complexes as a model for lignified grass walls, J. Agric. Food Chem. 44 (1996) 1453-1459.

[98] M.D. Casler, H.G. Jung, Selection and evaluation of smooth bromegrass clones with divergent lignin and etherified ferulic acid concentration, Crop Sci. 39 (1999) $1866-1873$.

[99] M.D. Casler, H.G. Jung, Relationships of fibre, lignin, and phenolics to in vitro fibre digestibility in three perennial grasses, Anim. Feed Sci. Technol. 125 (2006) 151-161.

[100] M.D. Casler, H.G. Jung, W.K. Coblentz, Clonal selection for lignin and etherified ferulates in three perennial grasses, Crop Sci. 48 (2008) 424-433.

[101] H.G. Jung, R.L. Phillips, Putative seedling ferulate ester (sfe) maize mutant: morphology, biomass yield, and stover cell wall composition and rumen degradability, Crop Sci. 50 (2010) 403-418.

[102] H.G. Jung, D.R. Mertens, R.L. Phillips, Impact of reduced ferulate-mediated lignin/arabinoxylan cross linking in corn silage on feed intake, digestibility. and milk production, J. Dairy Sci. 94 (2011) 5124-5137.

[103] R.A.C. Mitchell, P. Dupree, P.R. Shewry, A novel bioinformatics approach identifies candidate genes for the synthesis and feruloylation of arabinoxylan, Plant Physiol. 144 (2007) 43-53.

[104] R. Nair, X. Bao, M. Tarczynski, et al., Is ferulic acid essential for hemicellulose (glucuronarabinoxylan) deposition in maize cell walls? Proc. XIth Cell Wall Mtg., 12-17 August 2007, Copenhagen, Denmark, Physiol. Plant. 130 (2007) Abstr. 121.

[105] R.B. Nair, K.L. Bastress, M.O. Riuegger, et al., The Arabidopsis thaliana REDUCED EPIDERMAL FLUORESCENCE1 gene encodes an aldehyde dehydrogenase involved in ferulic acid and sinapic acid biosynthesis, Plant Cell 16 (2004) 544-554.

[106] F. Piston, C. Uauy, L. Fu, et al., Down-regulation of four putative arabinoxylan feruloyl transferase genes from family PF02458 reduces ester-linked ferulate content in rice cell walls, Planta 231 (2010) 677-691.

[107] P.J. Harris, M.R. Kelderman, M.F. Kendon, et al., Monosaccharide compositions of unlignified cell walls of monocotyledons in relation to the occurrence of wall-bound ferulic acid, Biochem. Syst. Ecol. 25 (1997) 167-179.

[108] M.M. Buanafina, T. Langdon, B. Hauck, et al., Expression of a fungal ferulic acid esterase increases cell wall digestibility of tall fescue (Festuca arundinacea), Plant Biotechnol. J. 6 (2008) 264-280.

[109] M.M.D. Buanafina, T. Langdon, B. Hauck, et al., Targeting expression of a fungal ferulic acid esterase to the apoplast, endoplasmic reticulum or golgi can disrupt feruloylation of the growing cell wall and increase the biodegradability of tall fescue (Festuca arundinacea), Plant Biotechnol. J. 8 (2010) 316-331.

[110] K. Myton, S.C. Fry, Intraprotoplasmic feruloylation of arabinoxylans in Festuca arundinacea cell cultures, Planta 193 (1994) 326-330.

[111] J. Ralph, R.D. Hatfield, S. Quideau, et al., Pathway of $p$-coumaric acid incorporation into maize lignin as revealed by NMR, J. Am. Chem. Soc. 116 (1994) 9448-9456.

[112] J. Ralph, Hydroxycinnamates in lignification, Phytochem. Rev. 9 (2010)65-83

[113] R.D. Hatfield, J.M. Marita, K. Frost, Characterization of p-coumarate accumulation, $p$-coumaryl transferase, and cell wall changes during the development of corn stems, J. Sci. Food Agric. 88 (2008) 2529-2537.

[114] A. Ziebell, K. Gracom, R. Katahira, et al., Increase in 4-coumaryl alcohol units during lignification in alfalfa (Medicago sativa) alters the extractability and molecular weight of lignin, J. Biol. Chem. 285 (2010) 38961-38968.

[115] D.A. Samac, M. Tesfaye, M. Dornbusch, et al., A comparison of constitutive promoters for expression of transgenes in alfalfa (Medicago sativa), Transgenic Res. 13 (2004) 349-361.

[116] X. Liang, M. Dron, J. Schmid, et al., Developmental and environmental regulation of a phenylalanine ammonia-lyase $\beta$-glucouronidase gene fusion in transgenic tobacco plants, Proc. Natl. Acad. Sci. U. S. A. 86 (1989) 9284-9288.

[117] G. Gowri, N.L. Paiva, R.A. Dixon, Stress responses in alfalfa (Medicago sativa L.) 12. Sequence analysis of phenylalanine ammonia-lyase (PAL) CDNA clones and appearance of PAL transcripts in elicitor-treated cell cultures and developing plants, Plant Mol. Biol. 17 (1991) 415-429.

[118] N.L. Paiva, A. Oommen, M.J. Harrison, et al., Regulation of isoflavonoid metabolism in alfalfa, Plant Cell Tiss. Org. Cult. 38 (1994) 213-220.

[119] S. Pathirana, D.A. Samac, R. Roeven, et al., Analyses of phosphoenolpyruvate carboxylase gene structure and expression in alfalfa, Plant J. 12 (1997) 293-304.

[120] M.A. Schoenbeck, D.A. Samac, M. Fedorova, et al., The alfalfa (Medicago sativa) TDY1 gene encodes a mitogen-activated protein kinase homolog, Mol. PlantMicrobe Interact. 12 (1999) 882-893.

[121] C. Zhao, J.C. Craig, H.E. Petzold, et al., The xylem and phloem transcriptomes from secondary tissues of the Arabidopsis root-hypocotyl, Plant Physiol. 138 (2005) 803-818.

[122] J.-H. Ko,E.P. Beers, K.-H.Han, Global comparative transcriptome analysis identifies gene network regulating secondary xylem development in Arabidopsis thaliana, Mol. Genet. Genomics 276 (2006) 517-531.

[123] S.S. Yang, W.W. Xu, M. Tesfaye, et al., Transcript profiling of two alfalfa genotypes with contrasting cell wall composition in stems using a cross-species platform: optimizing analysis by masking biased probes, BMC Genomics 11 (2010) 323.

[124] J.-H. Ko, S.H. Yang, A.H. Park, et al., ANAC012, a member of the plant-specific NAC transcription factor family, negatively regulates xylary fiber development in Arabidopsis thaliana, Plant J. 50 (2007) 1035-1048. 
[125] C. Chen, H. Meyermans, B. Burggraeve, et al., Cell-specific and conditional expression of caffeoyl-coenzyme A-3-O-methyltransferase in poplar, Plant Physiol. 123 (2000) 853-868.

[126] J.C. Abbott, A. Barakate, G. Pinçon, et al., Simultaneous suppression of multiple genes by single transgenes. Down-regulation of three unrelated lignin biosynthetic genes in tobacco, Plant Physiol. 128 (2002) 844-853.

[127] A. Liu, R. Scorza, J.-M. Hily, et al., Engineering resistance to multiple Prunus fruit viruses through expression of chimeric hairpins, J. Am. Soc. Hortic. Sci. 132 (2007) 407-414.

[128] R. Zhong, Z.-H. Ye, Regulation of cell wall biosynthesis, Curr. Opin. Plant Biol. 10 (2007) 564-572.

[129] N. Mitsuda, A. Iwase, H. Yamamoto, et al., NAC transcription factors, NST1 and NST3, are key regulators of the formation of secondary walls in woody tissues of Arabidopsis, Plant Cell 19 (2007) 270-280.

[130] R. Zhong, E.A. Richardson, Z.-H. Ye, Two NAC domain transcription factors, SND1 and NST1, function redundantly in regulation of secondary wall synthesis in fibers of Arabidopsis, Planta 225 (2007) 1603-1611.

[131] H. Shen, X. He, C.R. Poovaiah, et al., Functional characterization of the switchgrass (Panicum virgatum) R2R3-MYB transcription factor PvMYB4 for improvement of lignocellulosic feedstocks, New Phytol. (2011), doi:10.1111/j.1469-8137.2011.03922.x.

[132] A.N. Olsen, H.A. Ernst, L.L. Leggio, et al., NAC transcription factors: structurally distinct, functionally diverse, Trends Plant Sci. 10 (2005) 79-87.

[133] J. Kim, J.-H. Jung, J.L. Reyes, et al., microRNA-directed cleavage of the ATHB15 mRNA regulates vascular development in Arabidopsis inflorescence stems, Plant J. 42 (2005) 84-94

[134] J.-H. Ko, C. Prassinos, K.-H. Han, Developmental and seasonal expression of PtaHB1, a Populus gene encoding a class III HD-Zip protein, is closely associated with secondary growth and inversely correlated with the level of microRNA (miR166), New Phytol. 169 (2006) 469-478.

[135] G.S. Chuck, C. Tobias, L. Sun, et al., Overexpression of the maize Corngrass 1 microRNA prevents flowering, improves digestibility, and increases starch content of switchgrass, Proc. Natl. Acad. Sci. U. S. A. (2011), doi:10.1073/pnas.1113971108.

[136] C. Lee, R. Zhong, E.A. Richardson, et al., The PARVUS gene is expressed in cells undergoing secondary wall thickening and is essential for glucuronoxylan biosynthesis, Plant Cell Physiol. 48 (2007) 1659-1672.

[137] C. Zhao, U. Avci, E.H. Grant, et al., XND1, a member of the NAC domain family in Arabidopsis thaliana, negatively regulates lignocellulose synthesis and programmed cell death in xylem, Plant J. 53 (2008) 425-436.

[138] R. Zhong, C. Lee, J. Zhou, et al., A battery of transcription factors involved in the regulation of secondary cell wall biosynthesis in Arabidopsis, Plant Cell 20 (2008) 2763-2782.

[139] P.S. Schnable, D. Ware, R.S. Fulton, et al., The B73 maize genome: complexity, diversity, and dynamics, Science 326 (2009) 1112-1115.

[140] A.H. Paterson, J.E. Bowers, R. Bruggmann, et al., The sorghum bicolor genome and the diversification of grasses, Nature 457 (2009) 551-556.

[141] H. Shen, Y. Yin, F. Chen, et al., A bioinformatic analysis of NAC genes for plant cell wall development in relation to lignocellulosic bioenergy production, Bioenergy Res. 2 (2009) 217-232.

[142] S. Fornale, X.H. Shi, C.L. Chai, et al., ZmMYB31 directly represses maize lignin genes and redirects the phenylpropanoid metabolic flux, Plant J. 64 (2010) 633-644.

[143] S. Fornale, F.M. Sonbol, T. Maes, et al., Down-regulation of the maize and Arabidopsis thaliana caffeic acid $O$-methyl-transferase genes by two new maize R2R3-MYB transcription factors, Plant Mol. Biol. 62 (2006) 809-823.

[144] F.M. Sonbol, S. Fornale, M. Capellades, et al., The maize ZmMYB42 represses the phenylpropanoid pathway and affects the cell wall structure, composition and degradability in Arabidopsis thaliana, Plant Mol. Biol. 70 (2009) 283-296.

[145] F. Guines, B. Julier, C. Ecalle, et al., Among and within-cultivar variability for histological traits of lucerne (Medicago sativa L.) stem, Euphytica 130 (2003) 293-301.

[146] N.J. Ehlke, M.D. Casler, Anatomical characteristics of smooth bromegrass clones selected for in vitro dry matter digestibility, Crop Sci. 25 (1985) 513-517.

[147] G. Sarath, K.P. Vogel, R.B. Mitchell, et al., Stem anatomy of switchgrass plants developed by divergent breeding cycles for tiller digestability, in: F.P. O'Mara, R.J. Wilkins, L. 't Mannetje, et al. (Eds.), XX International Grassland Congress:
Offered Papers, Wageningen Academic Publishers, Dublin, Ireland, 2005, p. 975.

[148] G.Sarath, D.E. Akin, R.B. Mitchell, et al., Cell-wall composition and accessibility to hydrolytic enzymes is differentially altered in divergently bred switchgrass (Panicum virgatum L.) genotypes, Appl. Biochem. Biotechnol. 150 (2008) 1-14.

[149] F.M. Engels, H.G. Jung, Alfalfa stem tissues: cell-wall development and lignification, Ann. Bot. 82 (1998) 561-568.

[150] B.S. Dien, L. Iten, C.D. Skory, Converting herbaceous energy crops to bioethanol: a review with emphasis on pretreatment processes, in: C.T. Hou (Ed.), Handbook of Industrial Biocatalysis, Taylor and Francis Group, Boca Raton, FL, 2005, pp. 1-11.

[151] H.G. Jung, R. Bernardo, Comparison of cell wall polysaccharide hydrolysis by a dilute acid/enzymatic saccharification process and rumen microorganisms, Bioenergy Res. (2011), http://www.springerlink.com/ openurl.asp?genre=article\&id=DOI 10.1007/s12155-011-9131-9.

[152] R. Kumar, C.E. Wyman, Does change in accessibility with conversion depend on both the substrate and pretreatment technology? Bioresour. Technol. 100 (2009) 4193-4202.

[153] K.C. Nlewem, M.E. Thrash Jr., Comparison of different pretreatment methods based on residual lignin effect on the enzymatic hydrolysis of switchgrass, Bioresour. Technol. 101 (2010) 5426-5430.

[154] J.A. Rollin, Z. Zhu, N. Sathitsuksanoh, et al., Increasing cellulose accessibility is more important than removing lignin: a comparison of cellulose solvent-based lignocellulose fractionation and soaking in aqueous ammonia, Biotechnol. Bioenergy 108 (2011) 22-30.

[155] S.L. Voelker, B. Lachenbruch, F.C. Meinzer, et al., Antisense down-regulation of $4 C L$ expression alters lignification, tree growth, and saccharification potential of field-grown poplar, Plant Physiol. 154 (2010) 874-886.

[156] H.D. Coleman, J. Yan, S.D. Mansfield, Sucrose synthase affects carbon partitioning to increase cellulose production and altered cell wall ultrastructure, Proc. Natl. Acad. Sci. U. S. A. 106 (2009) 13118-13123.

[157] M. Pauly, K. Keegstra, Plant cell wall polymers as precursors for biofuels, Curr. Opin. Plant Biol. 13 (2010) 305-312.

[158] M. Naoumkina, S. Vaghchhipawala, Y. Tang, Y. Ben, R.J. Powell, R.A. Dixon, Metabolic and genetic perturbations accompany the modification of galactomannan in seeds of Medicago truncatula expressing mannan synthase from guar (Cyamopsis tetragonoloba L.), Plant Biotechnol. J. 6 (2008) 619-631.

[159] N. Nishikubo, J. Takahashi, A.A. Roos, et al., Xyloglucan endo-transglycosylasemediated xyloglucan rearrangements in developing wood of hybrid aspen, Plant Physiol. 155 (2011) 399-413.

[160] D.M. Cavalier, O. Lerouxel, L. Neumetzler, et al., Disrupting two Arabidopsis thaliana xylosyltransferase genes results in plants deficient in xyloglucan, a major primary cell wall component, Plant Cell 20 (2008) 1519-1537.

[161] S. Hou, L. Li, Rapid characterization of woody biomass digestibility and chemical composition using near-infrared spectroscopy, J. Integr. Plant Biol. 53 (2011) 166-175.

[162] M.H. Studer, J.D. Demartini, M.F. Davis, et al., Lignin content in natural Populus variants affects sugar release, Proc. Natl. Acad. Sci. U. S. A. 108 (2011) 6300-6305.

[163] B.S. Dien, G. Sarath, J.F. Pedersen, et al., Improved sugar conversion and ethanol yield for forage sorghum (Sorghum bicolor L. Moench) lines with reduced lignin contents, Bioenergy Res. 2 (2009) 153-164.

[164] G. Sarath, B. Dien, S.J. Saathoff, et al., Ethanol yields and cell wall properties in divergently bred switchgrass genotypes, Bioresour. Technol. 102 (2011) 9579-9585.

[165] C. Fu, X. Xiao, Y. Xi, et al., Downregulation of cinnamyl alcohol dehydrogenase (CAD) leads to improved saccharification efficiency in switchgrass, Bioenergy Res. 4 (2011) 153-164.

[166] A.J. Saathoff, G. Sarath, E.K. Chow, et al., Downregulation of cinnamylalcohol dehydrogenase in switchgrass by RNA silencing results in enhanced glucose release after cellulase treatment, PLoS One 6 (1) (2011), doi:10.1371/journal.pone.0016416.

[167] B. Xu, L.L. Escamilla-Trevino, S. Noppadon, et al., Silencing of 4coumarate:coenzyme A ligase in switchgrass leads to reduced lignin content and improved fermentable sugar yields for biofuel production, New Phytol. (2011), doi:10.1111/j.1469-8137.2011.03830.x.

[168] B.W. Penning, C.T. Hunter 3rd, R. Tayengwa, et al., Genetic resources for maize cell wall biology, Plant Physiol. 151 (2009) 1703-1728. 